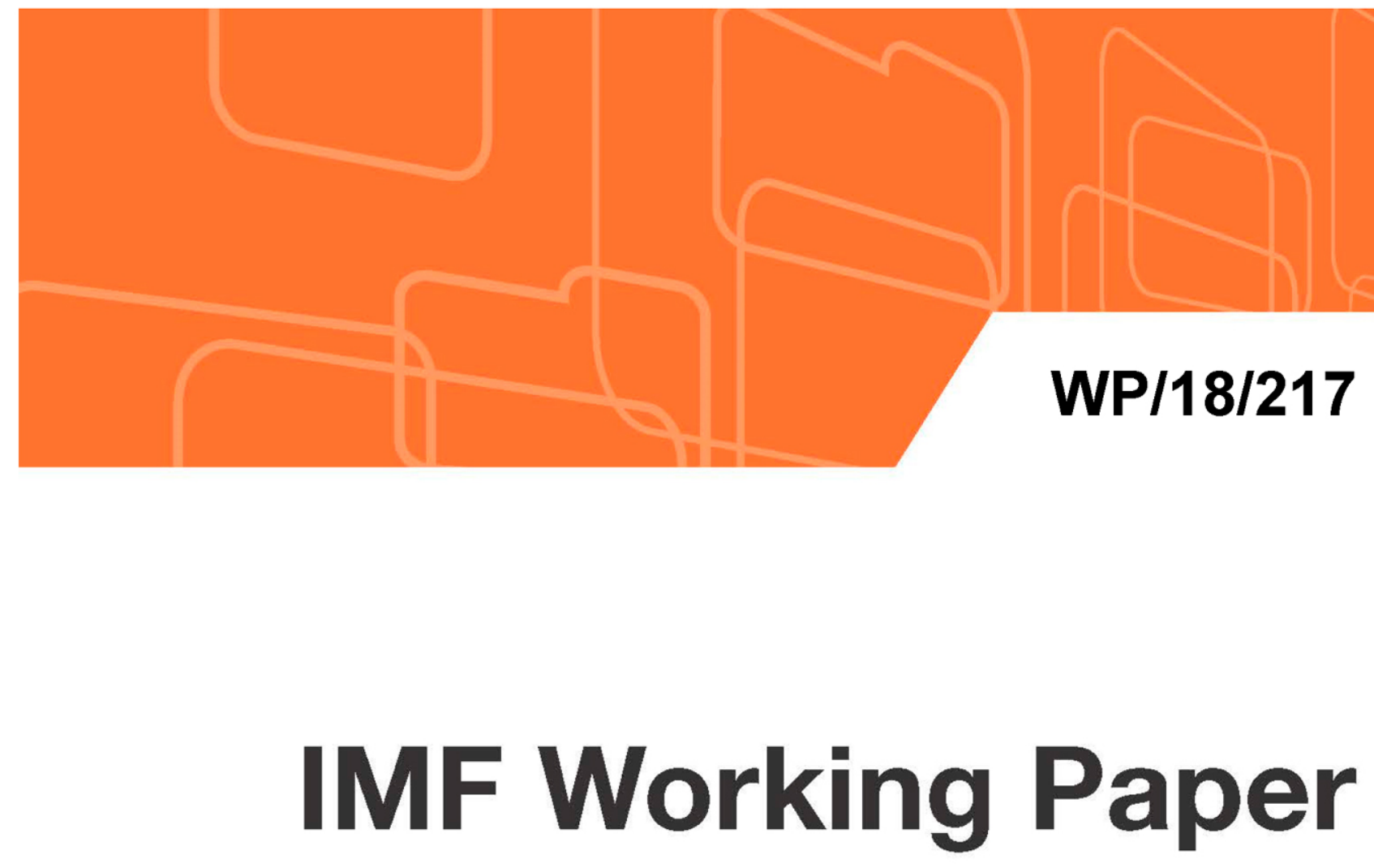

\title{
Cross-border Banking and the Circumvention of Macroprudential and Capital Control Measures
}

by Eugenio Cerutti and Haonan Zhou

IMF Working Papers describe research in progress by the authors and are published to elicit comments and to encourage debate. The views expressed in IMF Working Papers are those of the authors and do not necessarily represent the views of the IMF, its Executive Board, or IMF management. 


\section{WP/18/217}

\section{IMF Working Paper}

\section{Cross-border Banking and the Circumvention of Macroprudential and Capital Control Measures}

by Eugenio Cerutti and Haonan Zhou

IMF Working Papers describe research in progress by the authors and are published to elicit comments and to encourage debate. The views expressed in IMF Working Papers are those of the authors and do not necessarily represent the views of the IMF, its Executive Board, or IMF management. 


\title{
IMF Working Paper
}

\author{
Research Department \\ Cross-border Banking and the Circumvention of Macroprudential \\ and Capital Control Measures \\ Prepared by Eugenio Cerutti and Haonan Zhou*
}

Authorized for distribution by Maurice Obstfeld

September 2018

\begin{abstract}
IMF Working Papers describe research in progress by the author(s) and are published to elicit comments and to encourage debate. The views expressed in IMF Working Papers are those of the author(s) and do not necessarily represent the views of the IMF, its Executive Board, or IMF management.
\end{abstract}

\begin{abstract}
We analyze the joint impact of macroprudential and capital control measures on cross-border banking flows, while controlling for multidimensional aspects in lender-and-borrower-relationships (e.g., distance, cultural proximity, microprudential regulations). We uncover interesting spillover effects from both types of measures when applied either by lender or borrowing countries, with many of them most likely associated with circumvention or arbitrage incentives. While lender countries' macroprudential policies reduce direct cross-border banking outflows, they are associated with larger outflows through local affiliates. Direct cross-border inflows are higher in borrower countries with more usage of macroprudential policies, and are linked to circumvention motives. In the case of capital controls, most spillovers seem to be present through local affiliates. We do not find evidence to support the idea that additional capital inflow controls could interact with macro-prudential policies to mitigate cross-border spillovers.
\end{abstract}

JEL Classification: F42, G15, G21

Keywords: Cross-Border Banking Flows, Macroprudential Policies, Capital Controls

Authors’ E-Mail Addresses: ecerutti@imf.org, haonan@princeton.edu

\footnotetext{
* Cerutti is at Research Department of the International Monetary Fund, and Haonan Zhou at Princeton University. We are grateful to Tamin Bayoumi, Ruo Chen, Seung Mo Choi, Stijn Claessens, Giovanni Dell'Ariccia, Catherine Koch, Maury Obstfeld, Thorvardur Olafsson, Manasa Patnam, Erlend Nier, and Gregory Thwaites, seminar participants at the IMF, at the BIS, the 2018 ECB-IMF-BoE International Spillovers of Shocks and Macroeconomic Policies workshop at the BoE, and Paola Ganum for help with the data from the RES Bank Contagion Module. Authors' E-Mail Addresses: ecerutti@imf.org, haonan@princeton.edu. The opinions expressed herein are solely the responsibility of the authors and should not be interpreted as reflecting those of the IMF, its Executive Board, or IMF management.
} 
Contents

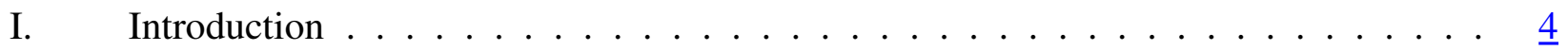

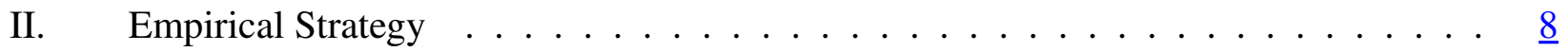

III. Do MPM and CCM generate international spillovers? Evidence from two-stage regressions . . . . . . . . . . . . . . . . . . . . 12

IV. Individual MPM and CCM: Uncovering heterogeneity and the potential presence of circumvention . . . . . . . . . . . . . . . . 14

V. Do policy interactions mitigate or augment the spillovers? . . . . . . . . . 15

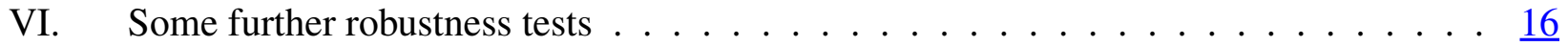

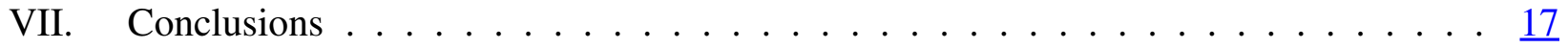

References . . . . . . . . . . . . . . . . . . . . . . 19

Figures

Figure 1: Global usage of macroprudential instruments and capital controls _. . . . . $2 \underline{3}$ Figure 2: Model prediction and counterfactual banking flows: Overall macroprudential policy . . . . . . . . . . . . . . . . . . 24

Figure 3: Model prediction and counterfactual banking flows: Overall capital flow re-

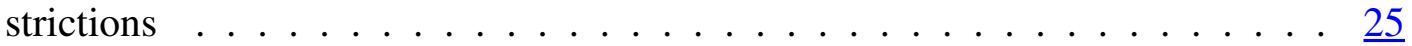

Figure 4: Interaction between macroprudential policy, capital control and direct cross-

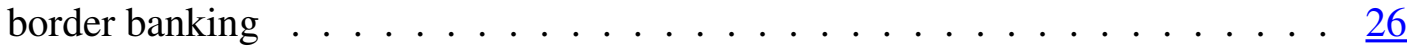

Tables

Table 1: Variable Definitions . . . . . . . . . . . . . . . . . 27

Table 2: $\quad$ Summary Statistics . . . . . . . . . . . . . . . . . $\underline{28}$

Table 3: $\quad$ Macroprudential policy, capital control and cross-border lending - first stage overall estimates . . . . . . . . . . . . . . . . . . . 29

Table 4: Macroprudential policy, capital control and cross-border lending - second stage overall estimates . . . . . . . . . . . . . . . . . $\underline{30}$

Table 5: Macroprudential policy and cross-border banking - second-stage specific estimates . . . . . . . . . . . . . . . . . . 31

Table 6: Borrowers' macroprudential policy and cross-border banking: Interaction with credit cycles . . . . . . . . . . . . . . . . . . . 32

Table 7: Macroprudential policy and cross-border banking - second-stage specific estimates, AE/EMDE breakdown . . . . . . . . . . . . . . 33

Table 8: Capital control and cross-border banking - second-stage specific estimates . . . $\underline{34}$ 
Table 9: Capital control measures and cross-border banking - second-stage specific es-

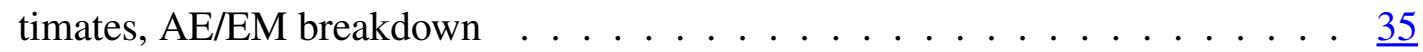

Table 10: MPM, CCM and cross-border banking: robustness to right censoring . . . . . . $\underline{36}$

Table 11: MPM, CCM and cross-border banking: 2011-2015 sample estimates . . . . . . $\underline{37}$

Appendix A.1. Micro-found the empirical framework and counterfactual analysis . . . . $\underline{38}$

Appendix A.2. Additional Tables and Counterfactual Figures . . . . . . . . . . . . 41 


\section{INTRODUCTION}

One of the main lessons from recent financial crises is that monetary policy alone is not enough to achieve financial stability and/or to avoid undesirable consequences linked to surges in capital inflows. Initially, this conclusion was mainly perceived as relevant for emerging and developing markets (EMDEs), but it has been clearly extended to advanced economies (AEs) after the global financial crisis of 2008 (GFC). Nowadays, the usage of a broader set of instruments, in which Macroprudential Policy Measures (MPM) and Capital Control Measures (CCM) can play key roles, is considered as preferable in many circumstances. ${ }^{1}$ Indeed, as Figure 1 suggests, global usage of both MPM and CCM has been increasing, especially after the GFC. AEs initially lagged behind in terms of the number of MPM, but all AEs are now equipped with at least one instrument, and their average number of instruments outweigh those of EMDEs. Meanwhile, despite an early decline, the share of countries adopting $\mathrm{CCM}$ has been on a steady rising trend, with EMDEs using more controls than AEs. In general, the impact of CCM and MPM has been widely analyzed in the literature, but most studies analyze CCM or MPM separately, with few papers considering them simultaneously, and accounting for policy interactions. Moreover, among this last group of papers, the focus is on the impact on domestic credit markets rather than on cross-border dimensions. ${ }^{2}$

The objective of this paper is to fill this gap by analyzing together the potential impact of CCM and MPM on worldwide cross-border banking flows. Most CCM do not specifically target cross-border banking flows, but it is likely that they could directly or indirectly affect cross-border banking flows as they are designed to impact cross-border capital flows in general. Similarly, while authorities often employ MPM to target local bank lending, the resulting changes in the incentives of lenders and/or borrowers may generate spillover effects on cross-border banking flows. Hence, the analysis of the impact of both MPM and CCM on cross-border banking flows is key for understanding their effectiveness, as well as broader issues such as international cooperation. In addition to CCM and MPM, there are several other variables that can affect cross-border banking, from the degree of microprudential banking monitoring and supervision, and monetary policy more generally, to other multidimensional frictions captured by lender- and borrower-specific characteristics as well as bilateral linkages between the source and destination of financial flows (e.g. distance as a proxy of information asymmetries).

In this context, following the literature (e.g., Houston, Lin, and Ma, 2012, for an empirical assessment of cross-border lending/borrower in response to changes in micro-prudential regulations), the

\footnotetext{
${ }^{1}$ For example, Blinder et al (2017) document that central banks in both crisis and non-crisis countries report the implementation of macroprudential policies. The IMF adopted a new Institutional View on liberalization and management of capital flows in 2012, which does not rule out the maintenance of prudential measures nor the temporary re-imposition of capital flow measures under disorderly market circumstances and within a macroeconomic framework of consistent policies, if capital flows pose risks to macroeconomic or financial system stability (see IMF, 2016 for a recent review).

${ }^{2}$ See Buch and Goldberg (2017) for a review of several studies on the cross-border banking spillovers of macroprudential policies, and Ghosh, Qureshi, and Sugawara (2014) for the case of capital control measures. Bruno, Shim, and Shin (2017) considered both simultaneously, but they focused on 12 Asian economies without taking into account foreign affiliate local lending, and only MPM and CCM from the borrower country perspective. Akinci and OlmsteadRumsey (2015) also consider both borrowers' MPM and CCM simultaneously for 19 EMs in their analysis of domestic credit growth.
} 
use of bilateral cross-border banking data and a gravitational model seems an appropriate choice. Identification of the impact of MPM and CCM from lender/borrower countries favors the use of bilateral consolidated cross-border banking flows. BIS Consolidated Banking Statistics (CBS) not only provides us the most complete available global mapping of bilateral cross-border linkages, but it also allows us to distinguish between direct cross-border lending (e.g., the headquarters of a Spanish international bank lending directly to a Brazilian corporation) and lending through local affiliates (e.g., the lending from a foreign subsidiary and/or branch of the Spanish international bank operating in Brazil to a Brazilian corporation). This direct cross-border and local affiliate breakdown of cross-border lending is key to our type of analysis. Given that MPM target, by design, the activities of the local banking sector, direct cross-border lending may constitute one of the circumvention avenues to MPM. Similarly, CCM are not free of regulatory arbitrage opportunities; for example, Desai, Foley and Hines (2006) documented that U.S. multinational firms circumvent capital controls through their internal product and capital markets. ${ }^{3}$

In order to cover as many countries as possible, we use the widest currently available MPM and CFM datasets in terms of country coverage. More specifically, we use Cerutti, Claessens and Laeven (2017)'s dataset, the updated version of which now captures 12 macroprudential measures for 160 countries during 2000-17. We select measures of CCM from the dataset of Fernandez et al (2015), covering 100 countries from 1995 to 2015. As in Houston, Lin, and Ma (2012), we use the dataset from Barth, Caprio and Levine (2013) to proxy for the intensity of bank supervision and restrictions on non-core bank activities. Adopting the empirical strategy of Cerutti and Zhou (2018), which builds on Helpman, Melitz and Rubinstein (2008) and Fillat et al. (2018), we use a gravity equation derived from a model of heterogeneous banks extending international lending, in order to capture banks' selection into cross-border lending based on productivity differentials. This framework deals with empty bilateral banking relationships, particularly present in the case of banking exposure through local affiliates, that may introduce selection bias when estimated using conventional techniques such as ordinary least squares on a log-linear gravity equation of crossborder banking flows.

Through the use of regressions and counterfactual analyses, we uncover, both qualitatively and quantitatively, interesting spillover effects from both types of policy measures. For macroprudential policies, the overall usage of MPM in lender countries reduces direct cross-border lending, especially to EMDE borrowers. Lenders' leverage ratio requirement, interbank exposure limit and foreign currency loan limit, in particular, are associated with a lower level of direct crossborder banking outflows. Meanwhile, however, lenders' MPM are strongly associated with a higher level of lending through banks' local affiliates, reflecting the potentially significant role of banks' internal structure in bypassing regulatory constraints that could discourage direct crossborder lending (e.g., some MPM could be implemented only covering the bank headquarter's balance sheet and not at a global consolidated level). Borrower countries' overall macroprudential measures have a statistically significant positive impact on direct cross-border banking inflows, and

\footnotetext{
${ }^{3} \mathrm{~A}$ further disaggregation of either direct cross-border or affiliate local lending by the type of borrower (private, bank, and non-bank private sector) is not available in BIS CBS at ultimate risk basis (i.e. the data identifies the ultimate source and destination of banking flows). It is also not possible to distinguish affiliates into subsidiaries and branches. BIS CBS at ultimate risk basis takes into account the potential reallocation of claims (via guarantees and other risk transfers) to reflect the location of the ultimate counterparty/risk.
} 
yield an expected negative (yet insignificant) effect on lending through local affiliates. ${ }^{4}$ At a more disaggregate level, borrower countries tend to receive higher direct cross-border banking inflows after adopting interbank exposure limits and foreign currency loan limits. These results are robust to adding either domestic credit booms or regional cross-border general inflows-which tend to be followed by tightening regulatory measures-into our estimations, suggesting that alternative factors such as domestic or regional credit booms could not explain the association between MPM and cross-border banking flows. Rather, the association is more likely due to motives to circumvent.

In the case of capital control measures, we find a strong association of lenders' capital outflow restrictions with higher local affiliate lending, primarily through affiliates in advanced economies, and especially large when lenders restrict outward bond investments. Borrowers' CCM on inflows also lead to higher borrowing through local affiliates. Overall, the findings add to the notion that local affiliates may function as important avenues for cicumventing CCM restrictions on cross-border capital flows. The impact of either lender and borrowers' CCM on direct crossborder lending is sometimes statistically significant (e.g. Lenders' bond outflows restrictions increase direct cross-border lenting to EMDEs), but are usually small in size. There are also some interesting insights from the results of interacting both MPM and CCM together. We do not find consistent evidence that borrowers' $\mathrm{CCM}$ can help mitigate the potential increase in direct cross-border inflows due to the circumvention of domestic macroprudential regulations.

Our findings complement and make several contributions to the literature. First, our findings confirm and extend the analysis on the cross-border spillovers of macroprudential policies. From the borrowers' perspective, Cerutti, Claessens, and Laeven (2017) show that greater use of macroprudential policies increases the ratio of cross-border to domestic borrowing. Similarly, Akinci and Olmstead-Rumsey (2015) find that total credit, which includes direct cross-border flows, is less responsive to macroprudential policies than domestic lending is. Using BIS CBS data, Reinhardt and Sowerbutts (2016) find that foreign banks increase foreign claims (a sum of direct cross-border and local affiliate lending) to borrower countries with tighter macroprudential regulations, especially with increased capital standards. Avdjiev et al. (2017) report, using an OLS approach on a cross-sample of 53 countries, that a tightening of reserve requirements or LTV limits by a borrower country is associated with an increase in international bank lending (a sum of direct cross-border and local affiliate lending in foreign currency). Our findings are in a similar direction, but, in addition to controlling for CCM, we further test the circumvention hypothesis with the presence of domestic and regional cross-border booms as well as we stress the differences between direct cross-border and local affiliate lending. While the overall usage of MPM in the borrower country triggers larger direct cross-border inflows - which seems to be associated with circumvention motives - the opposite seems to be happening with local affiliate lending. From the lender countries' perspective, Buch and Goldberg (2017) report that the tightening of prudential requirements increases Canadian, French, Italian and Dutch international banks' lending abroad, but the results are also sometimes in the inverse direction for other banking systems (e.g., US and German banks). ${ }^{5}$ They also highlight differences in the responses to MPM by German banks as a func-

\footnotetext{
${ }^{4}$ Borrowers' MPM target the lending by local affiliates, especially in the case of foreign subsidiaries.

${ }^{5}$ The reported findings by Buch and Goldberg (2007) correspond to their outward transmission to foreign
} 
tion of the type of cross-border lending (subsidiaries vs. direct cross-border lending). Baskaya, Binici and Kenc (2017) report that a tightening of LTV limits in lender countries seems to lead to higher cross-border borrowing by banks in Turkey. Similarly, Avdjiev et al. (2017) find that better-capitalized banking systems tend to increase their international claims by more in the face of tighter LTV requirements in their home country. These results highlight the presence of heterogeneity and the fact that our differentiation between direct cross-border and local affiliates could also be important from the lender perspective. Not all lenders' MPM are implemented at the international group consolidated basis as highlighted by Buch and Goldberg (2017).

Second, our findings are related to several studies on the effectiveness of CCM on cross-border banking flows. For example, Ghosh, Qureshi, and Sugawara (2014), using locational BIS data, report that $\mathrm{CCM}$ at either the lender or borrower country ends can influence the volume of crossborder bank flows. With regard to inflow CCM by the borrower country, Bruno, Shim, and Shin (2017) find that banking inflow CCM are associated with lower growth in cross-border banking inflows for Asian countries. Our results highlight more the impact through local affiliates, but, more generally, they are closer to the large body of empirical research that finds limited effects (see Klein, 2012). We do not find much spillovers or power to offset circumvention of MPM. ${ }^{6}$ Interestingly, although we do not find that bond market inflow restrictions at the borrower country level are associated with larger direct cross-border banking borrowing, our positive impact in terms of flows through local affiliate could explain the positive spillover with respect to overall crossborder flows (which includes both direct cross-border and other intergroup cross-border flows) pointed out in Bruno, Shim, and Shin (2017). A related type of cross-type arbitrage has also been documented by Ahnert, Forbes, Friedrich, and Reinhardt (2017), who show that some corporates respond to reduced lending from banks (due to foreign currency MPM) by increasing their foreign currency debt issuance.

Third, our findings provide further evidence to the literature highlighting the importance of global banks' internal capital markets in cross-border banking. Cetorelli and Goldberg (2012) show that global banks actively manage liquidity through internal funding reallocations. Aiyar, Calomiris, and Wieladek (2014) find that in response to higher capital requirements for UK local banks, foreign banks' branches operating in the UK increased their share of local lending, a sign of regulatory arbitrage. Cerutti and Claessens (2017) highlight how banks used direct cross-border loans and local affiliate lending differently during the global financial crisis, when capital and liquidity were "trapped" and/or "ring-fenced" within affiliates. They resorted to sharp declines in direct cross-border lending which were (partially) covered by affiliate lending as a way to circumvent ring fencing restrictions. Our finding of circumvention of MPM and specially CCM through affiliate local lending points into a similar direction.

Fourth, our paper contributes to the growing literature that attempts to use bilateral banking statis-

economies' results, which captures the effect of foreign prudential policies on the activities of a reporting country's global banks. The approach used in those analyses does not cover the prudential policy in the reporting country itself.

${ }^{6}$ Although we do not find large effects from borrowers' CCM - which could be supporting either relatively nonbinding enough measures or that the effect is captured by other control variables (e.g. microfinancial regulation) - the fact that borrowers' CCM cannot offset circumvention triggered by borrowers' MPM, seems to reinforce the idea that borrowers' CCM might have limited direct effects. 
tics to study the evolution of global banking and its interaction with financial regulations. Houston, Lin and Ma (2012) find evidence that before the Global Financial Crisis, banks engaged in regulatory arbitrage by shifting funds to markets with fewer restrictions. Similarly, Ongena, Popov and Udell (2013) study a sample of bank-firm lending of emerging Europe, and find that a lower bank lending standard is associated with tighter restrictions on bank activities and higher minimum capital requirement in domestic markets. As the Global Financial Crisis prompts the emergence of a stricter worldwide regulatory environment, recent literature suggests that banks expand their lending to regional partners with more restrictions on bank activities (Claessens and van Horen, 2015, Cerutti and Zhou, 2018).

Finally, in terms of policy implications, even though our findings are based on aggregate country data and using coarse measures of MPM and CCM, we detect the presence of spillovers that mean that MPM and CCM are sometimes binding. Nonetheless, our mixed results on the effect of MPM-CCM interactions suggest that countries may find their combined general usage ineffective at curbing unwanted banking spillovers without targeting the specific potential channel of policy leakages. This finding empirically questions, to some extent, the theoretical complementarity in the usage of MPM and CCM highlighted by Korinek and Sandri (2016). In this context, our analysis based on aggregate data points towards the need for more cooperation and coordination between regulators in the global context, especially in the case of foreign affiliates and when spillovers are economically significant, as a way to reduce unintended spillovers of domestic policies and achieve better risk-sharing. This is in line with earlier calls for international cooperation in macroprudential policies by, among others, IMF-FSB-BIS (2016), Agenor and Pereira da Silva (2018), and Choi et al (2018).

This paper is organized as follows: Section 2 provides an overview on our empirical framework and data used for the analysis. Section 3 focuses on the impact of overall MPM and CCM on crossborder banking flows. Section 4 examines the effects of MPM and CCM at individual instrument's level. Section 5 discusses our findings on the interaction between MPM and CCM. Section 6 reports results of robustness checks, and Section 7 concludes.

\section{EMPIRICAL STRATEGY}

We embed our gravity equation in the two-step empirical framework proposed by Cerutti and Zhou (2018). Originally used by Helpman, Melitz and Rubinstein (2008) in the context of estimating trade flows, we derive the same expression from a model of heterogenous banks making decisions to expand internationally through direct cross-border lending and/or local affiliate lending. The model explicitly takes into account the presence of zero banking flows due to unobserved, bankspecific productivity differences that sort the banks into groups making cross-border loans and groups that do not. Formally, letting $i$ denote lender and $j$ denote borrower, our framework can be formulated as follows: ${ }^{7}$

\footnotetext{
${ }^{7}$ In Appendix A1, we provide a sketch of the derivation from a model of heterogenous banks making direct crossborder and local affiliate loan decisions.
} 
First stage: estimate the Probit equation

$$
\rho_{i j t}=\operatorname{Pr}\left(T_{i j t}=1\right)=\Phi\left(\alpha_{t}+\psi_{i}+\chi_{j}+\beta_{1} r_{i t}+\theta_{1} r_{j t}+\gamma_{1} d_{i j}+\kappa \zeta_{i j t}\right)
$$

where $T_{i j t}$ is an indicator of connection between lender $i$ and borrower $j$ at time $t . \quad r_{i t}$ and $r_{j t}$ represent, respectively, lender- and borrower-specific characteristics, potentially time-varying. These characteristics include regulation intensity and other control variables. $d_{i j}$ denotes a set of time-invariant bilateral gravity factors, including geographical distance and common language. $\zeta_{i j t}$ is a set of variables, exclusively used in the first stage to control for additional barriers to banking flows. The use of $\zeta_{i j t}$ is common in a traditional Heckman-style estimation of models with selection bias. In the model, $\zeta_{i j t}$ can be interpreted as fixed cost shifters. $\Phi($.$) is the cumulative$ distribution function of a standard normal distribution.

Second stage: estimate the non-linear equation

$$
Y_{i j t}=\tau_{t}+\lambda_{i}+\xi_{j}+\beta_{2} r_{i t}+\theta_{2} r_{j t}+\gamma_{2} d_{i j}+\ln \left\{\exp \left[\delta\left(z_{i j t}+\eta_{i j t}\right)\right]-1\right\}+\beta \eta_{i j t}+e_{i j t}
$$

where $z_{i j t}$ is calculated from the inverse of predicted probability of connection from the first stage: $z_{i j t}=\Phi^{-1}\left(\rho_{i j t}\right) . \eta_{i j t}$ denotes the inverse Mills ratio: $\eta_{i j t}=\frac{\phi\left(z_{i j t}\right)}{\Phi\left(z_{i j t}\right)}$. The inverse Mills ratio term, together with the non-linear term $\ln \left\{\exp \left[\delta\left(z_{i j t}+\eta_{i j t}\right)\right]-1\right\}$ (derived from the assumption that latent bank productivity in our model follows a truncated Pareto distribution, see Appendix A1), corrects the selection bias generated by the impact of country-level barriers on banks' internationalization decisions, identical across banks, as well as the possibly heterogenous response of individual banks to financial barriers due to differences in productivity. ${ }^{8}$ We exploit the distributional assumption of the error term $e_{i j t} \sim N\left(0, \sigma^{2}\right)$ to estimate the equation via Maximum Likelihood.

Our main dataset of bilateral lending comes from the ultimate risk Consolidated Banking Statistics (CBS) provided by the Bank for International Settlements. The CBS data capture the consolidated claims of internationally active banks headquartered in BIS reporting countries. Intragroup positions are netted out. The nationality-based nature of CBS makes it ideal for analyzing the true bilateral exposure with less concern for intragroup transactions as well as double-counting due to the existence of financial centers that largely serve the purpose of intermediation. ${ }^{9}$ Since variations in regulatory intensity from source or destination countries as well as the nature of both may not only affect banks' direct cross-border lending decisions, but also induce changes in the activities of banks' foreign affiliates (branches and subsidiaries), the availability of both components in CBS allows us to separately examine the impact of different policy instruments on direct cross-border and local affiliate flows. For the local affiliate component, we further adjust the data downwards using deposit-loan ratio, following Cerutti (2015), to avoid overstating the size of bilateral local affiliate exposure when the affiliates are primarily funded by local deposits. Similar to Houston, Lin and Ma (2012) and Karolyi, Sedunov and Taboada (2017), most of our policy instruments and control variables are in annual frequency, so we use end-of-year observations to collapse our

\footnotetext{
${ }^{8}$ Buch, Koch and Koetter (2014) and Niepmann (2016), among others, argue that banks' modes of foreign operations and volume of foreign activities crucially depend on differences in productivity.

${ }^{9}$ See Cerutti and Zhou (2017) for a discussion of the advantages of using BIS CBS when mapping the cross-border banking network.
} 
quarter banking flows dataset to annual frequency.

We transform the annual banking claims at year $t$ into flows by taking the difference between claims at years $t$ and $t-1$, and define our dependent variables at both stages as:

$$
\begin{gathered}
Y_{i j t}=\max \left(0, X_{i j t}-X_{i j(t-1)}\right) \\
T_{i j t}=I\left(Y_{i j t}>0\right)
\end{gathered}
$$

where $I($.$) is the indicator function. By definition, a lender is connected to a borrower if within the$ year, it increases its exposure to the borrower. ${ }^{10}$ Our final dataset covers banking flows from 29 BIS reporting countries (lenders) to over 160 borrowers from 2006 to 2015.

Our main variables of interest are measures of regulations related to financial intermediation and banking. We select from three categories of policy instruments: macroprudential regulation, capital control and bank non-core activity restriction to capture, as broadly as possible, the different impact of policy instruments on global cross-border banking. For macroprudential policy, we use a recently updated version of the database compiled by Cerutti, Claessens and Laeven (2017), which, among other sources, takes advantage of the IMF's 2017 Macroprudential Policy Survey (IMF 2018). The dataset covers the use of twelve MPM for 160 countries over the period of 2000 to 2017. We use the composite measure - overall macroprudential index (MPI) based on 12 types of macroprudential measures - to proxy for the overall usage of macroprudential policy measures by a country. In addition, we estimate individual macroprudential instruments' effect on international banking, selecting leverage ratio requirement, loan-to-value limit and limit on interbank exposure and foreign currency loan from all twelve instruments. We also select measures of CCM from the dataset of Fernandez et al (2015), covering 102 countries from 1995 to 2015 . $^{11}$ The dataset is compiled from IMF's Annual Report on Exchange Arrangements and Exchange Restrictions, documenting the types and directions of restrictions on ten types of cross-border capital transactions using binary indicators. The composite measure - overall capital outflow (inflow) restriction index - is the sample average of all ten outflow (inflow) restriction dummies. For individual capital control measures, we focus on restrictions on bond investment, commercial credit and foreign credit. ${ }^{12}$ Taking intersections with the coverage of CCM, MPM and other

\footnotetext{
${ }^{10}$ Consistent with our model setup, an increase in exposure suggests a net issuance of new cross-border lending by banks in the reporting country within a full year. $35.5 \%(4.8 \%)$ of the zeros in our direct cross-border (local affiliate) sample are driven by our requirement of positive net lending, with the $64.5 \%(95.2 \%)$ remaining due to the nonexistence of a bilateral lending linkage between lender and borrowers. Our dependent variable definition is different from Houston, Lin and Ma, (2012) and Karolyi, Sedunov and Taboada (2017), who use censored log differences (growth rate) of exposures-bilateral observations with growth rate above 100 percent are deleted in order to control for outliers. Our baseline definition remains consistent with our modelled two-step procedure, and alleviates concerns that observations are dropped during early years on the banking relationship between a lender and a borrower country (with small initial lending), or when there is high variability in the level of claims if we follow Houston et al. (2012). Notwithstanding the caveats, Appendix A2, Table A2(d) presents estimation results based on alternative definitions of the dependent cross-border flow variable, including dropping observations with a decrease in bilateral exposure (negative flows), or using log difference as second-stage dependent variables and accordingly redefining first-stage dependent variables. See also Section 6.

${ }^{11}$ The original Fernandez et al. (2015) dataset comes with 100 countries. We hand-collect data from AREAER using the same methodology for Luxembourg, and combine information from Taiwan Province of China to ensure our CCM variables cover all 29 lenders in our sample.

${ }^{12}$ While some capital control measures have prudential implications, they explicitly target cross-border capital
} 
controls, we work with 29 lenders and 86 borrowers from 2006 to 2015 - maintaining a global coverage while ensuring time-series and cross-sectional variations of our data is sufficient. We can distinguish between inflow and outflow CCM, so we select outflows in the case of lenders and inflows in the case of borrower countries. 13 Finally, we use the variable "bank activity restriction" from Barth, Caprio and Levine (2013) to proxy for the intensity of bank supervision and restrictions on non-core bank activities. Banks make lending decisions based on existing regulatory barriers. To alleviate the concern of endogeneity due to timing, we use policy instruments lagged by one year in our estimation, so that the baseline specification accordingly becomes:

$$
\begin{gathered}
\rho_{i j t}=\operatorname{Pr}\left(T_{i j t}=1\right)=\Phi\left(\alpha_{t}+\psi_{i}+\chi_{j}+\beta_{1} r_{i t-1}+\beta_{1}^{x} x_{i t}+\theta_{1} r_{j t-1}+\theta_{1}^{x} x_{j t}+\gamma_{1} d_{i j}+\kappa \zeta_{i j t}\right) \\
Y_{i j t}=\tau_{t}+\lambda_{i}+\xi_{j}+\beta_{2} r_{i t-1}+\beta_{2}^{x} x_{i t}+\theta_{2} r_{j t-1}+\theta_{2}^{x} x_{j t}+\gamma_{2} d_{i j}+ \\
\ln \left\{\exp \left[\delta\left(z_{i j t}+\eta_{i j t}\right)\right]-1\right\}+\beta \eta_{i j t}+e_{i j t}
\end{gathered}
$$

where $r_{k t-1}$ exclusively denotes the lagged policy instruments of country $k \in\{i, j\}$ and $X_{k t}$ denotes other contemporaneous lender- or borrower-specific controls.

We follow previous literature on regulation and global banking to choose our control variables. In particular, Houston, Lin and Ma (2012) argue that institutional quality is an important indicator of the level of regulatory arbitrage in international banking before the crisis. We include the Fraser Institute's property right index in our estimation to control for this effect. Recent literature on prudential policy spillovers also includes a proxy for financial cycle using measures related to credit-to-GDP (e.g., Avdjiev et al., 2017). We compile quarterly measures of nominal credit to GDP from IMF International Financial Statistics to better reflect domestic credit situation for both the lender and the borrower. Real GDP growth of the lender and the borrower is included to further control for the demand side of international banking. Finally, we control for the impact of monetary policy by including a variable covering policy-related interest rate or short-term lending rate (discount rate), similar to Correa et al. (2018).

We include a parsimonious set of traditional gravity factors in our estimation, using log geographical distance and a dummy for common official language from CEPII (Head et al., 2010; Head and Mayer, 2014) to control for distance effect and cultural proximity. Adding additional bilateral linkages, such as colonial relation dummy, does not change our quantitative results. Finally, we follow Helpman, Melitz and Rubinstein (2008), Buch, Koch and Koetter (2014) and Cerutti and Zhou (2018) to develop instruments $\zeta_{i j t}$ in the first stage. For direct cross-border lending, we construct a synthetic indicator of banks' overhead cost to total assets, assigning value one only if both the lender and the borrower have above-median costs. For local affiliate lending, in addition to the indicator of high overhead cost, we also include an indicator of free-trade agreement (Buch, Koch and Koetter, 2014) and indicators of high costs and long time to set up firms (Helpman,

flows by definition. On the other hand, macroprudential policy measures typically are not exclusively applied to regulating cross-border capital flows. To maintain the distinction, we recode the raw data from the IMF 2017 Macroprudential Survey in the rare cases that the reported presence of a macroprudential instrument was assessed based on measures covering only a cross-border dimension (e.g., Saudi Arabia was recorded as having foreign currency lending limits based only on restrictions on nonresident lending. We corrected that classification). As a result, our MPM and CCM policy dummies and composite measures are independent and have little actual overlaps.

${ }^{13}$ In both Cerutti, Claessens, and Laeven (2017) and Fernandez et al (2015), the implicit assumption is that a country would actively use an instrument/measure once it is written into a law or into regulatory rules. 
Melitz and Rubinstein, 2008), since local affiliates may subject to similar procedures governing firm entry. A detailed list of variables used can be found in Table 1. Table 2 reports the summary statistics.

\section{DO MPM AND CCM GENERATE INTERNATIONAL SPILLOVERS? EVIDENCE FROM TWO-STAGE REGRESSIONS}

Tables 3 and 4 report the first-stage and second-stage regressions results of a set of regressions based on the two-stage model described in Section 2. We start from the most parsimonious specification - that is, using only the traditional gravity factors and push-pull variables identified in Section 2, without adding any regulatory measures, and then we add MPM and CCM separately, and then both types of regulations, as well as authorities' restrictions on domestic banks' non-core activities into the regressions. The latter are introduced in order to account for any possible regulatory arbitrage effects observed by Houston, Lin and Ma (2012) on the side of micro-prudential supervision and monitoring. The following results are worth highlighting:

First, in general, traditional factors enter the regression with the expected signs. In particular, for both direct cross-border and local affiliate lending, lenders and borrowers' financial deepness (domestic credit to GDP) and the existence of a common language tie contribute positively to both the probability of net new lending (first stage), and the quantity of net new lending (second stage), while geographical distance serves as the major impediment to both modes of banking. The estimated elasticity of lending with respect to distance is around -0.5 for direct cross-border lending, and -1.5 for local affiliate lending, suggesting that the latter mode favors geographically closer partners even more. In addition, borrowers' GDP growth encourages new direct cross-border and local banking linkages, possibly signaling a higher demand for borrowing, while a higher institutional quality for borrowers is positively correlated with higher direct cross-border flows at both the first and second stages. For lenders, their economic growth and institutional quality also contribute to a higher direct cross-border flow, especially at the second-stage. In line with the literature, we also find mixed evidence in support of monetary policy as a significant driver of cross-border banking. While a monetary tightening in lender countries results in a lower probability of extending net new local affiliate lending, consistent with the push-pull literature (see Koepke, 2015), other effects are weak and do not seem to be highly significant across specifications.

Second, as the high overhead cost indicator and the free trade agreement indicator enter the firststage estimation with statistical significance for direct cross-border and local affiliate lending respectively, our use of exclusive first-stage variables assists in the identification of second-stage parameters. ${ }^{14}$ As shown in Table 4, the structural parameter proxying selection due to productivity heterogeneity is highly significant, while the traditional Heckman selection parameter is less so, suggesting that bank productivity heterogeneity indeed dominates in affecting banks' internationalization decisions.

\footnotetext{
${ }^{14}$ Our finding that the free-trade agreement dummy assist in the identification of local affiliate lending is consistent with Buch, Koch and Koetter (2014) evidence for German banks.
} 
Third, with the introduction of MPM (columns 2 and 6 of Tables 3 and 4) and CCM instruments (columns 3 and 7), separately, we find cross-border spillovers for both MPM and CCM. Moreover, despite the reduction in sample size in columns (4) and (8) as we are taking the intersection of countries for which all three types of measures (MPM, CCM, and micro-prudential) are available, several results from single-instrument regressions are still present. For MPM, while we find statistically significant evidence that lenders' overall MPM usage increases the probability that a new direct cross-border banking connection is formed (in the form of net new lending), the estimated elasticity of direct cross-border banking flows with respect to overall MPM is significantly negative, after controlling for CCM and non-core activity restrictions. Similarly, the negative relationship identified in the first stage between borrowers' overall MPM and direct cross-border does not translate to the flows. Instead, we find a strongly significant and positive association. There are no statistically significant relationships for local affiliate claims and borrowers' MPM. For CCM, Table 4, column 8 suggests that the elasticity of local affiliate flow to lenders' outflow restrictions is significantly positive, while borrowers' inflow restriction has a positive association with the probability of an increase in exposure through local affiliates. These findings provide early hints at global banks' possible circumvention of capital controls using local affiliates. Finally, there is evidence that the non-core activity restrictions (our proxy for micro-prudential) by lenders and/or borrowers favor an increase in both direct cross-border and local affiliate flows at the second-stage, consistent with Houston et al. (2012) findings for foreign claims.

We use the counterfactual analysis procedure outlined in Helpman, Melitz and Rubinstein (2008) and Appendix A1 to illustrate the relative economic magnitude of estimated coefficients, and to summarize both first and second stages. This is especially useful in the few cases when each stage has different signs. On the restricted sample that generates estimates of columns (4) and (8) in Tables 3 and 4, we construct the scenario under which all macroprudential or capital control measures are removed, calculate the aggregate global net positive increase in direct cross-border / local affiliate lending for countries with a history of adopting these measures in the data, and compare the counterfactual number with model predictions from actual data. The unique feature of our counterfactual analysis is that first-stage estimates also enter the picture through the estimated non-linear term in the second-stage, as a shift in barriers to banking affect the quantity of aggregate lending through its impact on whether or not banks are willing to increase their exposure, as well as the quantity of such an increase.

We first focus on MPM, with Figure 2 comparing model and counterfactual predictions on the effect of overall MPM on cross-border lending through the year 2006-2015. A higher counterfactual line than the model prediction line, suggests that lending in the context of assuming no restriction would be higher than what is predicted by the gravity model when actual restrictions are in place. In other words, it is hinting at the presence of negative spillovers the lenders' MPM. This is exactly what Figure 2 (top-left panel) suggests, consistent with the negative coefficients obtained from the second-stage regressions in Table 4. Figure 2 (top-right panel) indicates that local affiliate lending is higher with lenders' MPM. For borrowers' MPM, the bottom panels of Figure 2 show that there seems to be an increase in direct cross-border flows as the result of borrowers' MPM usage. The opposite seems to happen to local affiliate claims, an expected sign given that borrowers' MPM are also covering foreign affiliates, especially foreign subsidiaries. Similar to Figure 2, Figure 3 reports counterfactual predictions assuming overall CCM are shut down instead 
of overall MPM. Overall, the results highlight that there are spillovers from the usage of both lenders' and borrowers CCM on local affiliate lending. On the other hand, the overall quantitative impact of CCM on direct cross-border lending is small.

\section{INDIVIDUAL MPM AND CCM: UNCOVERING HETEROGENEITY AND THE POTENTIAL PRESENCE OF CIRCUMVENTION}

\section{Macroprudential Policy Measures}

Having established the validity of model estimates and some overall findings for overall MPM, we go further and investigate cases of specific MPM, while controlling for other types of regulatory measures as in the columns (4) and (8) of Tables 3 and 4. Table 5 summarizes the results for macroprudential measures by reporting only the estimated coefficients of MPM variables of interest at the second stage. ${ }^{15}$ The overall effect of macroprudential policy masks heterogeneity for specific policy instruments. For direct cross-border lending, the negative overall effect on the lenders' side is clearly reflected in the leverage ratio, suggesting that balance sheet constraints on international banking groups have a material impact on their direct cross-border lending. ${ }^{16}$

The positive spillovers of borrowers' overall MPM usage on direct cross-border lending seems to be reflected in many individual macroprudential instruments (leverage ratio, interbank exposure limits, and foreign currency loan limits). These findings at individual instrument level, intuitively, tighten the connection of direct cross-border lending with borrowers' attempt to bypass domestic MPM. For example, as the authority restricts banks' ability to extend foreign currency loan, borrowers may look for alternative sources, including international lenders, to satisfy their foreign currency funding need. This type of correlation and motivation is something that the literature has already highlighted (e.g., Cerutti, Claessens, and Laeven 2017). Taking advantage of the bilateral nature of our data, we further examine alternative explanations for our findings and determine the nature of such spillovers. Are they signs of circumventing borrowers' MPM, or are they merely reflecting other phenomena that can simultaneously explain the increase in direct cross-border and the presence of borrowers' MPM? ${ }^{17}$ We can think of two channels that our original estimation might not be capturing. Even though we are controlling by borrower country GDP growth, this might not necessarily capture domestic credit booms where there could be an associated increase in direct cross-border banking flows together with more usage of MPM. Similarly, there could be

\footnotetext{
${ }^{15}$ In the rest of the paper, we present in the main text the second-stage estimations as the second-stage equations are the main gravity equations. As shown in Figures 2 and 3, second-stage coefficients play a larger role determining the overall magnitude of estimated spillovers. First stage marginal effects for individual policy instruments are reported in Appendix A2, Table A2 (a) and (b).

${ }^{16}$ Unlike the case of local affiliates, independent of whether or not lenders' MPM are implemented at the international group consolidated basis, direct cross-border flows are more likely to be affected by lenders' MPM as they are usually booked as part of the main banking group balance sheet. Further information on the geographical reach of lenders' MPM is not available for our sample.

${ }^{17}$ In our context, the issue is more of an omitted variable problem than other types of endogeneity in the MPM measure. The usage of MPM is not targeting cross-border flow but the domestic banking sector lending. We use a one-year lag of the MPM variable to address simultaneity and reflect the fact that banks make lending subject to existing regulations.
} 
the case of external banking inflows that are affecting a whole region (e.g., driven by the push variables often highlighted in literature since Calvo et al, 1993), increasing direct cross-border flows and reducing domestic bank credit. Table 6 reports the result of an augmentation of our model by adding the change of domestic credit to GDP and a variable that takes into account the cross-border banking inflows that each country's regional neighbors are receiving (weighted by the distance of each neighbor to each borrower country). In both cases, it is clear that the positive correlation of the overall and individual MPMs with direct cross-border flows survive the augmentation of the model, even with the introduction of interactions. Hence, the circumvention of borrowers' MPMs seems to be a plausible explanation of our previous results. ${ }^{18}$

On the other hand, the positive impact of lenders' MPM on local affiliate lending does not seem to be reflected in our selection of individual MPM, as shown in Table 5. Only in the case of lenders' overall MPM usage do we obtain statistically significant results, calling for further analysis on the differential impact of lenders' MPM based on heterogeneous country characteristics. Table 7 reports our findings of breaking down borrowers into AE and EMDE borrowers. The positive effect of lenders' overall MPM on local affiliate flows is primarily associated vis-à-vis AE borrowers. In particular, international banks seem to be able to circumvent lender (home) countries' leverage ratio and interbank exposure limits through their affiliate network with AE countries. On the other hand, we find significantly negative effects of lenders' MPM on direct cross-border lending to EMDE borrowers, both in overall usage and across individual instruments. This finding reflects the effects of various macroprudential regulations in prompting global banks to scale back operations and reduce global footprints, as documented in the literature (see Claessens, 2017 for a recent review).

\section{Capital Control Measures}

Similar to Table 5, Table 8 reports our estimation results using individual-instrument breakdowns for CCM. The positive and significant association between lenders' outflow restrictions and local affiliate flows partly reflects substitution across different types of investments: local affiliate flows tend to rise as lenders establish bond outflow restrictions. Meanwhile, inflows through local affiliates are higher when borrowers adopt restrictions on lending by nonresidents - another signal of policy circumvention. While for direct cross-border lending, the coefficients of credit outflow restrictions are positive and significant, this result could partially be reconciled by the fact that a number of credit control measures do not target banks, but are directed towards non-bank institutions such as pension funds and insurance companies.

\section{DO POLICY INTERACTIONS MITIGATE OR AUGMENT THE SPILLOVERS?}

We have seen in Section 4 that the use of borrowers' MPM may induce spillovers through an increase in cross-border lending, and that such an increase is possibly associated with the intention of circumvention. Similarly, but in an opposite direction, we find that lenders' MPM was associated with a decrease in direct cross-border lending. An interesting question to ask is whether

\footnotetext{
${ }^{18}$ We report the results of the same exercise applied to capital control measures in Appendix A2, Table A2(c).
} 
there exists a policy mix with CCM that could dampen or amplify the spillover effect of those macroprudential measures. While it is beyond the scope of this paper to provide a full-fledged theoretical analysis, we use our empirical framework to investigate the additional effect of MPM and CCM mixes on cross-border lending, by introducing sets of interactions separately into the regressions. We summarize two interesting results in Figure 4, which show the estimated base-level and interaction effects and their statistical significance.

The results suggest that interaction effects are not uniform across the different type of instruments. For example, the top panel of Figure 4 shows that lenders' leverage ratio negative spillovers would increase in the simultaneous presence of CCM (as captured by the overall capital outflow restriction index). In the same line, the bottom panel of Figure 4 indicates that there is no consistent evidence that borrowers' CCM could have limited the circumvention of borrowers' MPM. Only in the case of borrowers' interbank exposure limits does the presence of CCM seem to have statistically offset the circumvention in our sample. In addition, the lack of significant impact of the interaction of MPM and CCM on direct cross-border flows helps us in classifying the nature of borrowers' CCM. In principle, the fact that we do not find large effects from borrowers' CCM on cross-border banking inflows support the idea that CCM are not binding enough, which is in line with the limited CCM effects found by a large part of the literature (See Klein, 2012). The results that borrowers' CCM cannot offset circumvention triggered by borrowers' MPM, seems to reinforce this finding that borrowers' CCM have limited effects.

\section{SOME FURTHER ROBUSTNESS TESTS}

We have shown that our results were robust to different specifications and data breakdowns. This section presents two additional tests. Following the literature, Table 10 show the results (second stage estimations) of truncating observations where the year to year growth rate of the cross-border flows is above the $95^{\text {th }}$ percentile of the distribution. This would control for break in series and the presence of outliers. Results are very similar to what we reported before for both MPM and CCM.

Similarly, and more importantly in terms of the size of the data sample, we restrict the estimation to the period 2011-2015, instead of the original 2006-2015. This allows us to fully exclude the GFC from the estimations. The results for MPM, as shown in the top panel of Table 11, are very similar. Lenders' MPM seems to trigger negative spillovers into direct cross-border flows not only in terms of the overall index, but also individual measures like the leverage ratio, interbank exposure limits and foreign currency loan restrictions. As before, lenders' overall MPM seem to trigger positive spillovers through local affiliate lending. On the borrowers' side, their MPM usage seems to trigger circumvention through an increase of direct cross-border flows. This leakage seems to be statistically significant in the case of the overall index, the leverage ratio, foreign currency loan limits, and also, for the first time, with regard to LTVs.

Further robustness tests are presented in Appendix A2, Table A2(d). Estimation results based on alternative definitions of the dependent cross-border flow variable, including dropping observations with a decrease in bilateral exposure (negative flows), or using log difference as second-stage 
dependent variables and accordingly redefining first-stage dependent variables, display similar results, especially in the case of MPM. This is not surprising, given that our baseline estimationswhich are designed to control for the important presence of zero banking flows-would be biased against finding the effect of lenders' MPM since our baseline estimations would only rely on positive deaccelerations of net flows after MPM (not eventual negative net flows). In addition, as a further comparison, Table A2(d) also presents results obtained from OLS estimates (instead of our two stage estimations), and the Pseudo Poisson Maximum Likelihood (PPML) estimators suggested by Santos Silva and Tenreyro (2006). Notwithstanding the bias introduced by log-linearization, the OLS estimates, especially in the case of lenders' MCM and CCM, are close to our baseline estimates. ${ }^{19}$

\section{CONCLUSIONS}

In this paper, we use a structural gravity approach to investigate the spillovers of MPM and CCM in the form of cross-border banking flows. We start by introducing MPM and CCM instruments into an otherwise standard bank gravity equation, but accounting for the selection bias generated by non-positive banking flows. We find that substantial policy spillovers seem to exist, some of them possibly associated with circumvention motives. In general, we find that the MPM spillovers seem to be more prevalent than CCM. Our distinction between direct cross-border and local affiliate lending finds some significant positive relationships between several capital outflow control measures and cross-border flows into local affiliates. The impact of MPM seems to be broader. Lenders' MPM not only reduce direct cross-border flows but also can trigger some increase in local affiliate lending. Borrowers' MPM, on the other hand, seem to trigger some circumvention that is reflected in an increase in direct cross-border flows. Estimated effects of MPM interaction with CCM are not uniform across policy macroprudential instruments. While further borrower capital inflow controls may avoid part of the borrowers' macroprudential policy circumvention, the effect does not seem large in the aggregate and is very heterogenous with respect to individual variables.

Our findings have rich policy implications. Our empirical results indicate that agents often do react to CCM and especially MPM by directly or indirectly adjusting their international lending / borrowing decisions, thus triggering international spillovers. From the lenders' perspective, the circumvention of some lenders' MPM through affiliate lending raises the need for a wider approach to risk-taking and connectedness, one that includes the behavior of their banks' local affiliates. From the perspective of borrower countries, policy makers should be aware that the implementation of MPM may trigger unintended spillovers / exposure through cross-border banking linkages. There is not much evidence that CCM can avoid this circumvention of macroprudential policies. Moreover, borrower countries have to be aware that lenders' MPM might trigger spillovers through

\footnotetext{
${ }^{19}$ The PPML estimators generate different results compared to our baseline estimates. However, as shown by Martin and Pham (2015) and Martinez-Zarzoso (2013), the performance of PPML estimator is highly contingent on the underlying data-generating process. Although the PPML estimator is more robust to heteroskedastic errors, it does not effectively correct for the selection bias generated by excessive zeroes in the data, especially when the existence of zeroes is due to structural reasons. In fact, the Monte Carlo study conducted by Martin and Pham (2015) show that PPML could be severely biased assuming some specific data-generating processes.
} 
the reduction of direct cross-border banking flows, especially to EMDE borrowers. In this context, at a more global level, it is clear that further analysis of the impact of post-crisis financial regulatory reform remains a highly relevant and interesting avenue for future research, as well as the possible benefit of cross-border coordination and cooperation to reduce the found spillovers of domestic MPM and CCM policies and achieve better risk-sharing. 


\section{REFERENCES}

Agenor, Pierre-Richard, and Luiz Pereira da Silva. 2018. "Financial spillovers, spillbacks, and the scope for international macroprudential policy coordination.” BIS Papers No 97.

Ahnert, Toni, Kristin Forbes, Christian Friedrich, and Dennis Reinhardt. 2017. "Macroprudential FX regulation: Shifting the snowbanks of FX vulnerability?" Working Paper.

Akinci, Ozge, and Jane Olmstead-Rumsey. 2015. "How effective are macroprudential policies? An empirical investigation.” International Finance Discussion Papers 1136.

Avdjiev, Stefan, and Elod Takats. 2016. "Monetary policy spillovers and currency networks in cross-border bank lending." BIS Working Paper No. 549.

Avdjiev, Stefan, Catherine Koch, Patrick McGuire, and Goetz von Peter. 2017. "International Prudential Policy Spillovers: A Global Perspective." International Journal of Central Banking 13: 5-32.

Barth, James R, Gerard Caprio, and Ross Levine. 2013. "Bank Regulation and Supervision in 180 Countries from 1999 to 2011.” NBER Working Paper 18733.

Baskaya, Yusuf Soner, Mahir Binici, and Turalay Kenc. 2017. "International banking and crossborder effects of regulation: Lessons from Turkey." International Journal of Central Banking 13 (S1): 379-403.

Berrospide, Jose M, Ricardo Correa, Linda S. Goldberg, and Friederike Niepmann. 2017. "International banking and cross-border effects of regulation: Lessons from the United States." International Journal of Central Banking 13: 435-476.

Blinder, Alan, Ehrmann Michael, Jakob de Haan, and David-Jan Jansen. 2017. "Necessity as the mother of invention: Monetary policy after the crisis.” Economic Policy 32 (92): 707-755.

Bremus, Franziska, and Marcel Fratzscher. 2015. "Drivers of structural change in cross-border banking since the global financial crisis." Journal of International Money and Finance 52: $32-59$.

Bruno, Valentina, and Hyun Song Shin. 2015. "Cross-border banking and global liquidity." Review of Economic Studies 82: 535-564.

Bruno, Valentina, Ilhyock Shim, and Hyun Song Shin. 2017. "Comparative assessment of macroprudential policies.” Journal of Financial Stability 28: 183-202.

Buch, Claudia M, and Linda S Goldberg. 2017. "Cross-Border Prudential Policy Spillovers: How much? How important? Evidence from the International Banking Research Network." International Journal of Central Banking 13 (S1): 505-558.

Buch, Claudia M., Catherine T. Koch, and Michael Koetter. 2014. "Should I stay or should I go? Bank productivity and internationalization decisions." Journal of Banking and Finance 42: 266-282. 
Calvo, Guillermo A., Leonardo Leiderman, and Carmen M. Reinhart. 1993. "Capital inflows and real exchange rate appreciation in Latin America: The role of external factors." IMF Staff Papers 40 (1): 108-151.

Cerutti, Eugenio, and Haonan Zhou. 2018. "Global Banking Network: What is Behind the Increasing Regionalization Trend?” IMF Working Paper 18/46.

Cerutti, Eugenio, and Haonan Zhou. 2017. "The Global Banking Network in the Aftermath of the Crisis: Is There Evidence of De-globalization?” IMF Working Paper 17/232.

Cerutti, Eugenio, and Stijn Claessens. 2017. "The great cross-border bank deleveraging: Supply constraints and intra-group frictions." Review of Finance 21 (1): 201-236.

Cerutti, Eugenio, Stijn Claessens, and Luc Laeven. 2017. "The Use and Effectiveness of Macroprudential Policies: New Evidence.” Journal of Financial Stability 28: 203-224.

Cetorelli, Nicola, and Linda S. Goldberg. 2012. "Liquidity management of U.S. global banks: Internal capital markets in the great recession." Journal of International Economics 88 (2): 299-311.

Claessens, Stijn. 2017. "Global Banking: Recent Developments and Insights from Research." Review of Finance 1513-1555.

Claessens, Stijn, and Neeltje van Horen. 2016. "The role of foreign banks in local credit booms." In The future of large, internationally active banks, by Asli Demirguc-Kunt, Douglas D. Evanoff and George G. Kaufman, 273-292. World Scientific.

Correa, Ricardo, Teodora Paligorova, Horacio Sapriza, and Andrei Zlate. 2018. "Cross-border bank flows and monetary policy." Working Paper.

Desai, Mihir A., C. Fritz Foley, and James R Hines Jr. 2006. "Capital controls, liberalizations, and foreign direct investment." Review of Financial Studies 19 (4): 1433-1464.

European Central Bank. 2017. "Financial Stability Review."

Fernandez, Andres, Michael Klein, Alessandro Rebucci, Martin Schindler, and Martin Uribe. 2015. “Capital Control Measures: A New Dataset." NBER Working Paper w20970, 548574.

Fillat, Jose L., Stefania Garetto, and Arthur V. Smith. 2018. "To branch or not to branch? A quantitative evaluation of the consequences of global banks' organization." Working Paper.

Forbes, Kristin, Dennis Reinhardt, and Tomasz Wieladek. 2017. “The spillovers, interactions, and (un)intended consequences of monetary and regulatory policies." Journal of Monetary Economics 85: 1-22.

Forbes, Kristin, Marcel Fratzscher, and Roland Straub. 2015. "Capital-flow management measures: What are they good for?” Journal of International Economics 96: S75-S97.

Ghosh, Atish R., Jonathan D. Ostry, and Mahvash S. Qureshi. 2017. "Managing the tide: How do emerging markets respond to capital flows?” IMF Working Paper 17/69. 
Ghosh, Atish R., Mahvash S. Qureshi, and Naokata Sugawara. 2014. "Regulating capital flows at both ends : Does it work?" IMF Working Paper 14/188.

Head, Keith, and Thierry Mayer. 2014. "Gravity Equations: Workhorse, Toolkit, and Cookbook.” Handbook of International Economics, 131-195.

Head, Keith, Thierry Mayer, and John Ries. 2010. "The erosion of colonial trade linakges after independence." Journal of International Economics 81 (1): 1-14.

Houston, Joel F, Chen Lin, and Yue Ma. 2012. "Regulatory Arbitrage and International Bank Flows." Journal of Finance 67 (5): 1845-1895.

IMF. 2016. "Capital flows: Review of experience with the institutional view.” IMF Policy Paper.

IMF. 2018. "The IMF's annual macroprudential policy survey-Objectives, design, and country responses." IMF Policy Paper.

IMF-FSB-BIS. 2016. "Elements of Effective Macroprudential Policies-Lessons from International Experience.” Available on: https://www.imf.org/external/np/g20/pdf/2016/083116.pdf.

Kang, Heedon, Francis Vitek, Rina Bhattacharya, Phakawa Jeasakul, Sonia Munoz, Naixi Wang, and Rasool Zandvakil. 2017. "Macroprudential Policy Spillovers: A Quantitative Analysis." IMF WP/17/170.

Karolyi, G. Andrew, John Sedunov, and Alvaro G. Taboada. 2017. "Cross-border bank flows and systemic risk." Working Paper.

Klein, Michael W. 2012. "Capital Controls: Gates versus Walls.” Brookings Papers on Economic Activity 2012 (1): 317-367.

Martin, Will, and Cong S. Pham. 2015. "Estimating the gravity model when zero trade flows are frequent and economically determined." World Bank Policy Research Working Paper No. 7308.

Martinez-Zarzoso, Inmaculada. 2013. “The log of gravity revisited." Applied Economics (45): 311-327.

Niepmann, Friederike. 2016. Banking Across Borders with Heterogeneous Banks. International Finance Discussion Papers 1177, Board of Governors of the Federal Reserve System.

Ongena, Steven, Alexander Popov, and Gregory F Udell. 2013. "When the cat's away the mice will play: Does regulation at home affect bank risk-taking abroad?" Journal of Financial Economics 108: 727-750.

Santos Silva, J.M.C., Tenreyro, Silvana. 2006. "The Log of Gravity." The Review of Economics and Statistics 88 (4): 641-658.

Seung, Mo Choi, Laura Kodres, and Jing Lu. 2018. "Friend or Foe? Cross-Border Linkages, Contagious Banking Crises, and "Coordinated"." IMF WP/18/9.

Temesvary, Judit, Steven Ongena, and Ann L. Owen. 2018. A global lending channel unplugged? Does U.S. monetary policy affect cross-border and affiliate lending by global U.S. banks? 
Finance and Economics Discussion Series 2018-008, Washington: Board of Governors of the Federal Reserve System. 


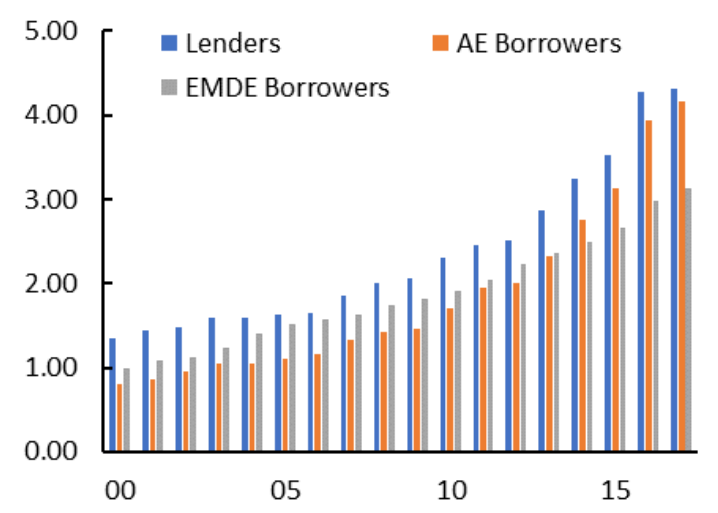

(a) Average number of macroprudential instruments

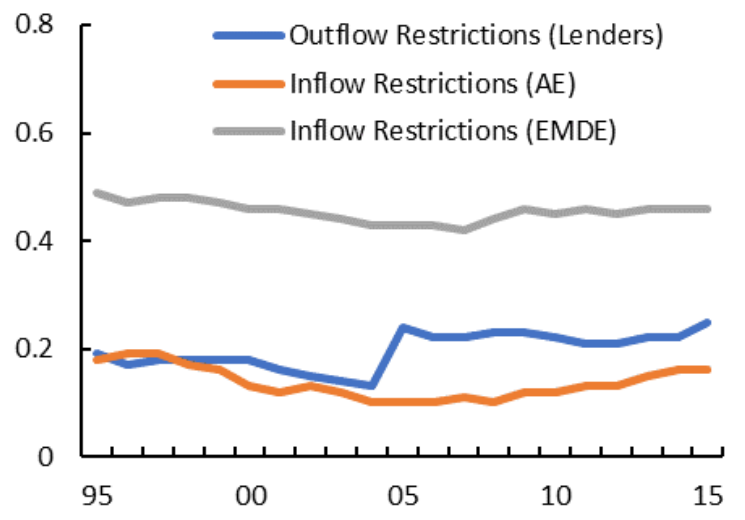

(c) Average capital control index

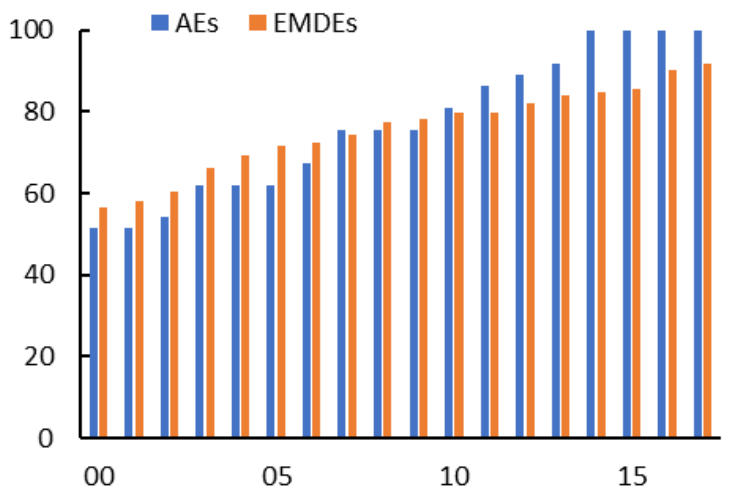

(b) Percentage of countries with macroprudential policy

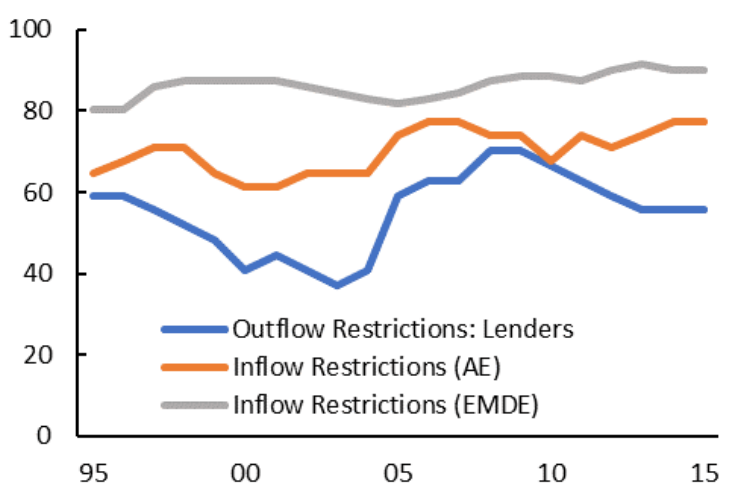

(d) Percentage of countries with capital controls

Figure 1: Global usage of macroprudential instruments and capital controls

Note: Figure 1 plots the time-series evolution of global usage of macroprudential instruments and capital controls. Data of panel (a) and (b) comes from Cerutti, Claessens and Laeven (2017), extended using responses to 2017 IMF Macroprudential Survey. Data on capital controls come from the capital control dataset of Fernandez et al. (2015), compiled from the IMF Annual Report on Exchange Arrangements and Exchange Restrictions. "Lenders" in the panels refers to 29 countries that report Consolidated Banking Statistics to the BIS ("reporting countries"). "Borrowers" refers to all counterparty countries of BIS reporting countries. Advanced (AE) and Emerging and Developing (EMDE) countries follow the definition of IMF World Economic Outlook. 

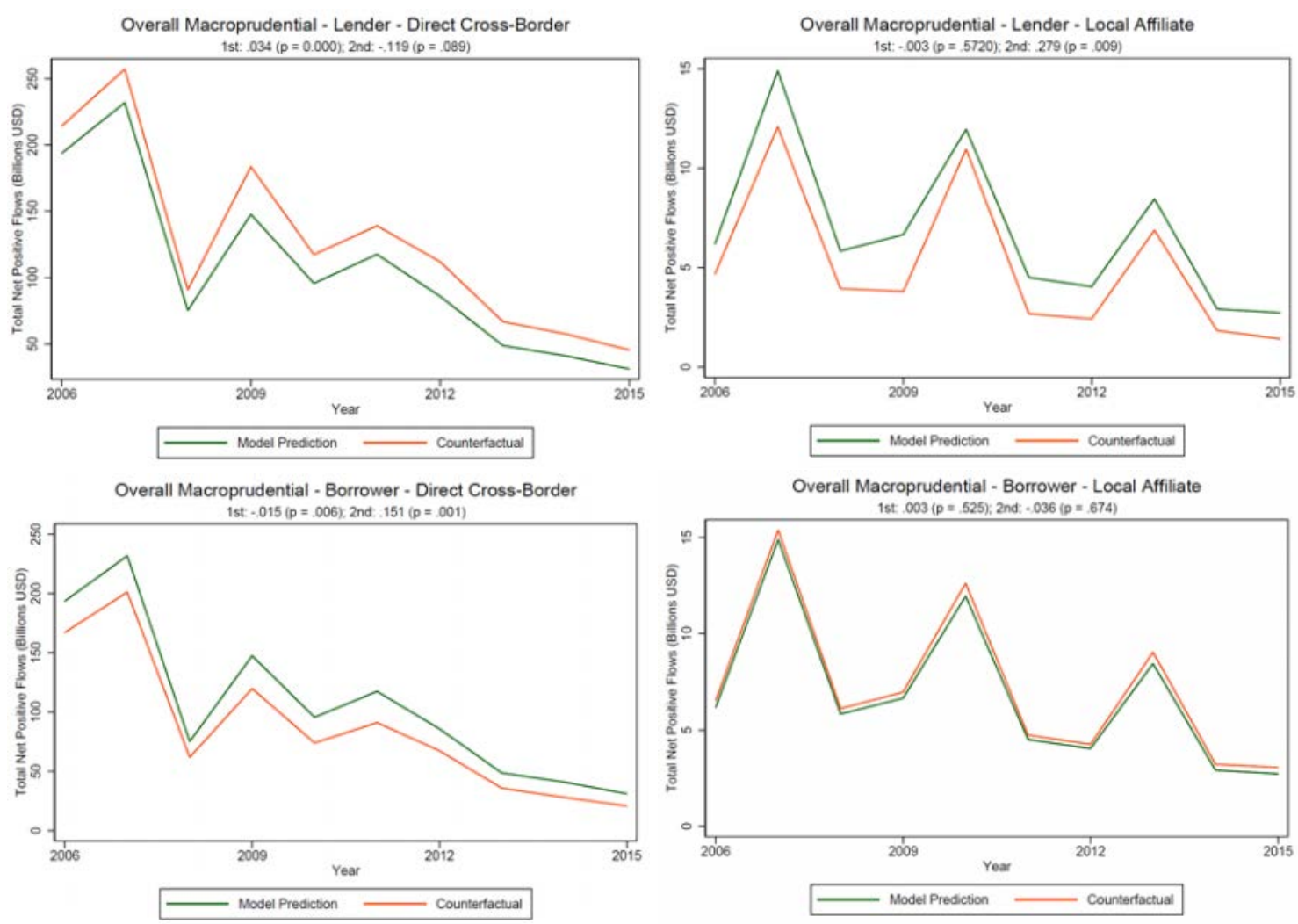

Figure 2: Model prediction and counterfactual banking flows: Overall macroprudential policy

Note: Figure 2 reports results of the counterfactual exercise detailed in Section 3 and Appendix A1. The variable of interest is oveall macroprudential policy index. "Model prediction" refers to the numbers predicted by the second-stage equation, using parameters estimated from true data. "Counterfactual" refers to the scenario where existing measures are switched off (for macroprudential policy index this means setting the index to zero). Counterfactual numbers are generated using the procedure outlined in Appendix A1. For each policy instrument, model prediction and counterfactual calculation are generated based on a sample of lenders/borrowers that have ever adopted this instrument. For each year, the magnitude of net positive increase in direct crossborder and local affiliate exposure is predicted for each country pair in the sample, and summed to global level. 

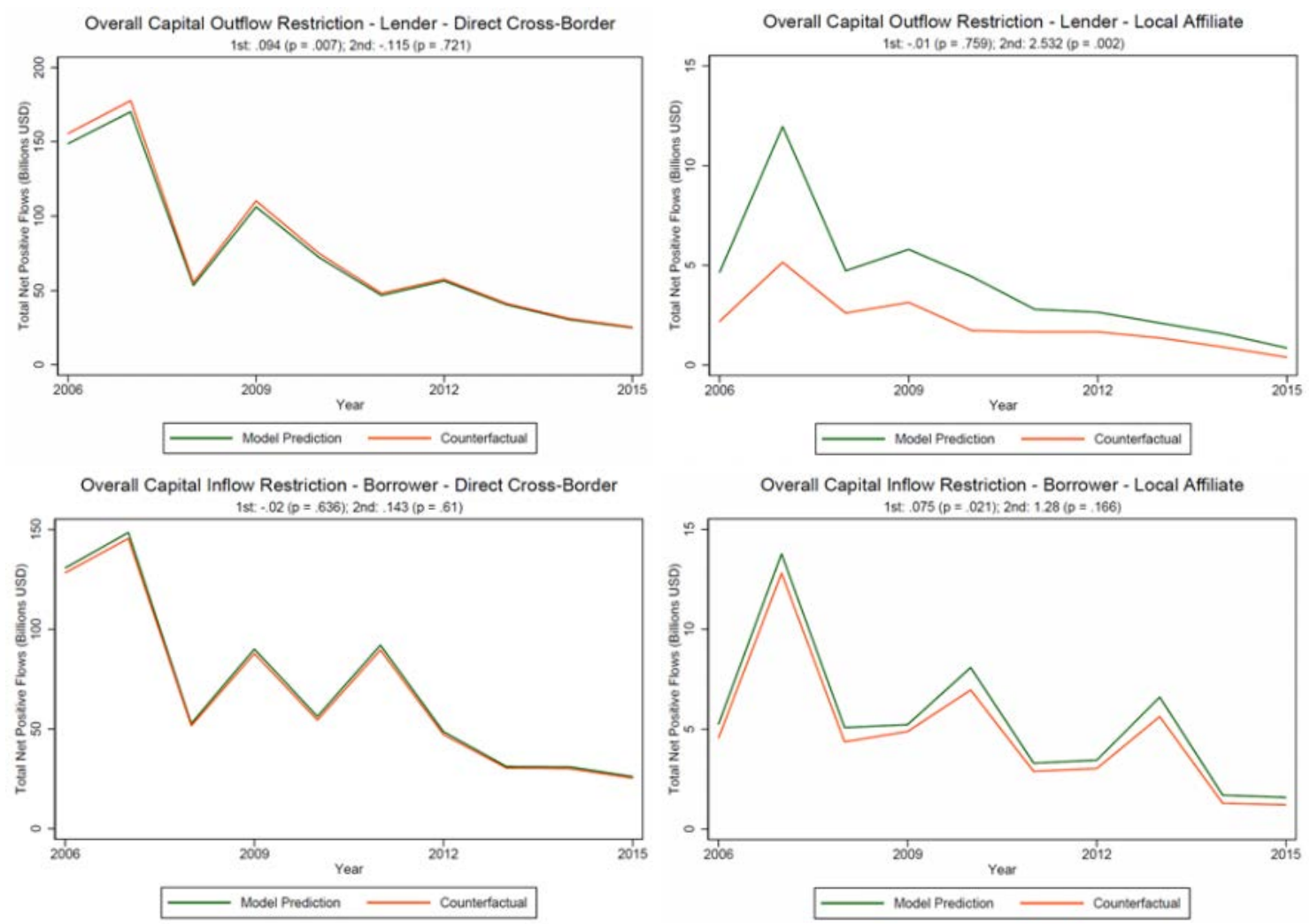

Figure 3: Model prediction and counterfactual banking flows: Overall capital flow restrictions

Note: Figure 3 reports results of the counterfactual exercise detailed in Section 3 and Appendix A1. The variable of interest is overall capital flow restrictions. "Model prediction" refers to the numbers predicted by the second-stage equation, using parameters estimated from true data. "Counterfactual" refers to the scenario where existing measures are switched off. Counterfactual numbers are generated using the procedure outlined in Appendix A1. For each policy instrument, model prediction and counterfactual calculation are generated based on a sample of lenders/borrowers that have ever adopted this instrument. For each year, the magnitude of net positive increase in direct cross-border and local affiliate exposure is predicted for each country pair in the sample, and summed to global level. 


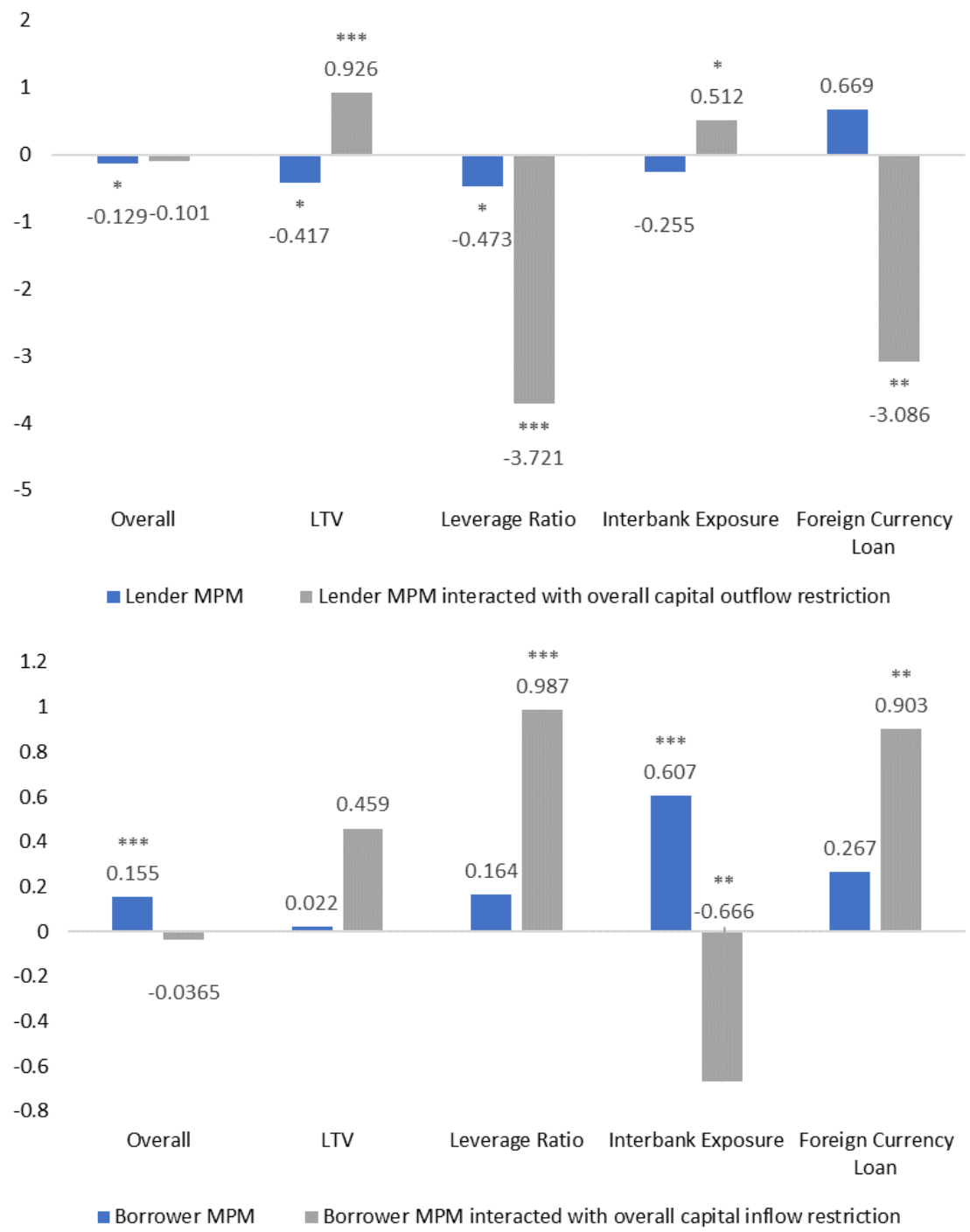

Figure 4: Interaction between macroprudential policy, capital control and direct cross-border banking

Note: Figure 4 displays two bar charts showing the estimated second-stage coefficients of lenders' (borrowers') macroprudential policy and its interaction with overall capital outflow (inflow) restrictions, with the size of net positive direct cross-border flows as dependent variable. The magnitudes of the coefficients as well as the significance levels (underlying standard errors clustered at lenderborrower level) are displayed. 


\begin{tabular}{|c|c|c|}
\hline Variables & Definition/Note & Source \\
\hline \multicolumn{3}{|l|}{ Dependent Variables } \\
\hline Direct Cross-Border Connection & \multirow{5}{*}{$\begin{array}{l}\text { For direct cross-border and local affiliate lending, } \\
\text { "connection" has value one if there is a year-over-year } \\
\text { increase in the corresponding type of exposure. Flow } \\
\text { is calculated as the log of the increase. Flow is zero if } \\
\text { no net new lending (no year-over-year increase) is } \\
\text { observed. See section } 2 \text { for details. }\end{array}$} & BIS Consolidated Banking Statistics \\
\hline Local Affiliate Connection & & BIS Consolidated Banking Statistics \\
\hline Direct Cross-Border Log Flow & & BIS Consolidated Banking Statistics \\
\hline Local Affiliate Log Flow & & \\
\hline & & BIS Consolidated Banking Statistics \\
\hline \multicolumn{3}{|l|}{ Gravity Factors and Instruments } \\
\hline Log Distance & \multirow{3}{*}{$\begin{array}{l}\text { Log geographical distance. } \\
\text { Has value one if speak the same official language. } \\
\text { Has value one if firm entry costs more than median } \\
\text { costs for both lender and borrower. }\end{array}$} & CEPII \\
\hline Common Official Language & & CEPII \\
\hline High Cost to Set up Firms & & CEPII \\
\hline High Time to Set up Firms & $\begin{array}{l}\text { Has value one if firm entry takes longer time than } \\
\text { median length for both lender and borrower. }\end{array}$ & CEPII \\
\hline High Overhead Cost & $\begin{array}{l}\text { Has value one if average ratio of overhead cost to bank } \\
\text { total assets is larger than median ratio for both lender } \\
\text { and borrower. }\end{array}$ & World Bank \\
\hline \multicolumn{3}{|l|}{ Control Variables } \\
\hline$\overline{\text { Policy / Short-term Interest Rate (Lagged) }}$ & Policy-related Interest Rate (Lagged) or discount rate. & $\begin{array}{l}\text { International Financial Statistics, Haver Analytics, } \\
\text { National Sources }\end{array}$ \\
\hline Legal System and Property Rights & $\begin{array}{l}\text { Aggregation of nine sub-components including } \\
\text { protection of property rights and legal enforcement of } \\
\text { contracts. }\end{array}$ & Fraser Institute \\
\hline Credit to GDP & $\begin{array}{l}\text { Nominal credit to GDP ratio (period end, in } \\
\text { percentages, seasonally adjusted). }\end{array}$ & International Financial Statistics \\
\hline Real GDP Growth & Annual growth rate of real GDP. & World Development Indicators \\
\hline \multicolumn{3}{|l|}{ Regulatory Measures } \\
\hline Macroprudential Instruments & \multirow{3}{*}{$\begin{array}{l}\text { Sum of all twelve available indices in the database. } \\
\text { Limits banks from exceeding a fixed minimum } \\
\text { leverage ratio. }\end{array}$} & \\
\hline Overall Prudential Index & & Cerutti, Claessens and Laeven (2017) \\
\hline Leverage Ratio & & Cerutti, Claessens and Laeven (2017) \\
\hline Loan-to-Value Limit & $\begin{array}{l}\text { Constrains highly levered mortgage down payments by } \\
\text { enforcing or encouraging a limit, or by determining } \\
\text { regulatory risk weights. }\end{array}$ & Cerutti, Claessens and Laeven (2017) \\
\hline Interbank Exposure Limit & $\begin{array}{l}\text { Limits the fraction of liabilities held by the banking } \\
\text { sector or by individual banks. }\end{array}$ & Cerutti, Claessens and Laeven (2017) \\
\hline $\begin{array}{l}\text { Foreign Currency Loan Limit } \\
\text { Capital Control Measures }\end{array}$ & Reduces vulnerability to foreign-currency risks. & Cerutti, Claessens and Laeven (2017) \\
\hline Overall Control & $\begin{array}{l}\text { Overall restriction index aggregating all asset } \\
\text { categories (equity, bonds, direct investment, credit, } \\
\text { etc.). Use outflow restriction for lenders and inflow } \\
\text { restrictions for borrowers. }\end{array}$ & Fernandez et al. (2015) \\
\hline Bond Control & $\begin{array}{l}\text { Restrictions on the purchase and issuance of bonds. } \\
\text { Use outflow restriction for lenders and inflow } \\
\text { restrictions for borrowers. }\end{array}$ & Fernandez et al. (2015) \\
\hline Commercial Credit Control & $\begin{array}{l}\text { Control on commercial credits directly linked with } \\
\text { international trade transactions or international } \\
\text { services. Use outflow restriction for lenders and inflow } \\
\text { restrictions for borrowers. }\end{array}$ & Fernandez et al. (2015) \\
\hline Foreign Credit Control & $\begin{array}{l}\text { Control on credit other than commercial credits } \\
\text { granted by all residents, including banks to } \\
\text { nonresidents, or vice versa. Use outflow restriction for } \\
\text { lenders and inflow restrictions for borrowers. }\end{array}$ & Fernandez et al. (2015) \\
\hline Bank Supervision & & \\
\hline Non-core Activities Restriction & $\begin{array}{l}\text { The extent to which banks may engage in security, } \\
\text { insurance and real estate business. Higher values } \\
\text { indicate greater restrictiveness. }\end{array}$ & Barch, Caprio and Levine (2013) \\
\hline
\end{tabular}

Table 1: Variable Definitions 


\begin{tabular}{|c|c|c|c|c|c|c|}
\hline VARIABLES & $\mathbf{N}$ & Mean & SD & Min & Max & Country/Pair \\
\hline \multicolumn{7}{|l|}{ Dependent Variables } \\
\hline Direct Cross-Border Connection & 55970 & 0.23 & 0.42 & 0 & 1 & 5597 \\
\hline Local Affiliate Connection & 55970 & 0.07 & 0.25 & 0 & 1 & 5597 \\
\hline Log Direct Cross-Border Flow & 12772 & -2.92 & 2.77 & -13.81 & 6.55 & 3216 \\
\hline Log Local Affiliate Flow & 3763 & -3.55 & 3.47 & -19.1 & 5.55 & 1234 \\
\hline \multicolumn{7}{|l|}{ Gravity Factors and Instruments } \\
\hline Log Distance & 5597 & 8.7 & 0.82 & 4.18 & 9.9 & 5597 \\
\hline Common Official Language & 5539 & 0.14 & 0.35 & 0 & 1 & 5539 \\
\hline High Cost to Set up Firms & 50901 & 0.06 & 0.24 & 0 & 1 & 5220 \\
\hline High Time to Set up Firms & 50901 & 0.12 & 0.32 & 0 & 1 & 5220 \\
\hline High Overhead Cost & 49737 & 0.06 & 0.24 & 0 & 1 & 5364 \\
\hline Free Trade Agreement (WTO) & 54230 & 0.22 & 0.41 & 0 & 1 & 5423 \\
\hline \multicolumn{7}{|l|}{ Control Variables } \\
\hline $\begin{array}{l}\text { Policy-related / Short-term Interest Rate: } \\
\text { Lender }\end{array}$ & 290 & 2.8 & 3.16 & 0.001 & 18 & 29 \\
\hline $\begin{array}{l}\text { Policy-related / Short-term Interest Rate: } \\
\text { Borrower }\end{array}$ & 1253 & 6.37 & 5.63 & 0.02 & 70 & 144 \\
\hline Legal System and Property Rights: Lender & 290 & 7.18 & 1.24 & 4.22 & 9.14 & 29 \\
\hline Legal System and Property Rights: Borrower & 1468 & 5.33 & 1.6 & 1.43 & 9.14 & 156 \\
\hline Credit to GDP: Lender & 290 & 105.11 & 43.12 & 16.51 & 233.21 & 29 \\
\hline Credit to GDP: Borrower & 1596 & 53.23 & 44.58 & 1.8 & 312.12 & 160 \\
\hline Real GDP Growth: Lender & 290 & 2.23 & 3.78 & -9.13 & 26.28 & 29 \\
\hline Real GDP Growth: Borrower & 1858 & 3.79 & 4.76 & -62.1 & 34.5 & 188 \\
\hline \multicolumn{7}{|l|}{ Regulatory Measures } \\
\hline \multicolumn{7}{|l|}{ Macroprudential Instruments } \\
\hline Overall Prudential Index: Lender & 290 & 2.26 & 1.57 & 0 & 7 & 29 \\
\hline Overall Prudential Index: Borrower & 1570 & 1.9 & 1.6 & 0 & 9 & 157 \\
\hline Leverage Ratio: Lender & 290 & 0.13 & 0.34 & 0 & 1 & 29 \\
\hline Leverage Ratio: Borrower & 1570 & 0.11 & 0.31 & 0 & 1 & 157 \\
\hline Loan-to-Value Limit: Lender & 290 & 0.31 & 0.46 & 0 & 1 & 29 \\
\hline Loan-to-Value Limit: Borrower & 1570 & 0.18 & 0.38 & 0 & 1 & 157 \\
\hline Interbank Exposure Limit: Lender & 290 & 0.33 & 0.47 & 0 & 1 & 29 \\
\hline Interbank Exposure Limit: Borrower & 1570 & 0.2 & 0.4 & 0 & 1 & 157 \\
\hline Foreign Currency Loan Limit: Lender & 290 & 0.07 & 0.26 & 0 & 1 & 29 \\
\hline Foreign Currency Loan Limit: Borrower & 1570 & 0.13 & 0.34 & 0 & 1 & 157 \\
\hline \multicolumn{7}{|l|}{ Capital Control Measures } \\
\hline Overall Outflow Control: Lender & 290 & 0.22 & 0.26 & 0 & 1 & 29 \\
\hline Overall Inflow Control: Borrower & 1020 & 0.34 & 0.31 & 0 & 1 & 102 \\
\hline Bond Outflow Control: Lender & 290 & 0.29 & 0.36 & 0 & 1 & 29 \\
\hline Bond Inflow Control: Borrower & 1016 & 0.33 & 0.4 & 0 & 1 & 102 \\
\hline Commercial Credit Outflow Control: Lender & 290 & 0.09 & 0.29 & 0 & 1 & 29 \\
\hline Commercial Credit Inflow Control: Borrower & 1017 & 0.23 & 0.42 & 0 & 1 & 102 \\
\hline Foreign Credit Outflow Control: Lender & 290 & 0.35 & 0.48 & 0 & 1 & 29 \\
\hline Foreign Credit Inflow Control: Borrower & 1020 & 0.35 & 0.48 & 0 & 1 & 102 \\
\hline \multicolumn{7}{|l|}{ Bank Supervision } \\
\hline Non-Core Activities Restriction: Lender & 272 & 6.54 & 1.97 & 3 & 10 & 29 \\
\hline Non-Core Activities Restriction: Borrower & 1280 & 7.71 & 1.93 & 3 & 12 & 152 \\
\hline
\end{tabular}

Table 2: Summary Statistics

Note: Table 2 reports summary statistics for the main variables used in the analysis. $\mathrm{N}$ denotes the unique number of non-missing observations. Country/pairs denote the number of unique country / country pairs for which data is available. 


\begin{tabular}{|c|c|c|c|c|c|c|c|c|}
\hline & \multicolumn{4}{|c|}{ Direct Cross-Border } & \multicolumn{4}{|c|}{ Local Affiliate } \\
\hline & \multirow{2}{*}{$\begin{array}{l}\text { Gravity } \\
\text { (1) }\end{array}$} & \multirow{2}{*}{ (2) ${ }^{\text {MPM }}$} & \multirow{2}{*}{ (3) $\mathrm{CCM}$} & \multirow{2}{*}{ (4) ${ }^{\text {All }}$} & \multirow{2}{*}{$\begin{array}{l}\text { Gravity } \\
\text { (5) }\end{array}$} & \multirow{2}{*}{ (6) ${ }^{\text {MPM }}$} & \multirow{2}{*}{ (7) ${ }^{\mathrm{CCM}}$} & \multirow{2}{*}{ (8) ${ }^{\text {All }}$} \\
\hline & & & & & & & & \\
\hline Overall macroprudential index & & $0.0225 * * *$ & & $0.0337 * * *$ & & -0.00219 & & -0.00280 \\
\hline (Lender) & & $(0.00373)$ & & $(0.00554)$ & & $(0.00351)$ & & $(0.00494)$ \\
\hline Overall macroprudential index & & $-0.0143 * * *$ & & $-0.0149 * * *$ & & 0.000873 & & 0.00292 \\
\hline (Borrower) & & $(0.00390)$ & & $(0.00542)$ & & $(0.00346)$ & & $(0.00459)$ \\
\hline Overall outflow restriction & & & $0.0516^{*}$ & $0.0944 * * *$ & & & 0.0330 & -0.00990 \\
\hline (Lender) & & & $(0.0298)$ & $(0.0353)$ & & & $(0.0284)$ & $(0.0323)$ \\
\hline Overall inflow restriction & & & 0.0172 & -0.0197 & & & $0.0863^{* * *}$ & $0.0746^{* *}$ \\
\hline (Borrower) & & & $(0.0340)$ & $(0.0417)$ & & & $(0.0306)$ & $(0.0324)$ \\
\hline \multirow[t]{2}{*}{ Activity restriction (Lender) } & & & & $-0.0127 * * *$ & & & & $0.0126^{* * *}$ \\
\hline & & & & $(0.00468)$ & & & & $(0.00423)$ \\
\hline \multirow[t]{2}{*}{ Activity restriction (Borrower) } & & & & 0.000977 & & & & $0.00736^{* *}$ \\
\hline & & & & $(0.00332)$ & & & & $(0.00313)$ \\
\hline Interest Rate (Lagged) & -0.00184 & -0.000531 & -0.00237 & $-0.00617^{*}$ & $-0.00407 * *$ & $-0.00446 * *$ & $-0.00377 *$ & 0.00256 \\
\hline (Lender) & $(0.00187)$ & $(0.00196)$ & $(0.00231)$ & $(0.00327)$ & $(0.00171)$ & $(0.00181)$ & $(0.00214)$ & $(0.00282)$ \\
\hline Interest Rate (Lagged) & -0.000484 & -0.000590 & -0.00184 & -0.00133 & 0.000100 & 0.0000761 & 0.000156 & 0.000514 \\
\hline (Borrower) & $(0.000817)$ & $(0.000846)$ & $(0.00124)$ & $(0.00168)$ & $(0.00108)$ & $(0.00110)$ & $(0.00132)$ & $(0.00169)$ \\
\hline Property Right & $0.0251 * *$ & $0.0444 * * *$ & $0.0288 * *$ & $0.0344 * *$ & 0.00623 & 0.00459 & 0.0112 & $0.0412 * * *$ \\
\hline (Lender) & $(0.00990)$ & $(0.0107)$ & $(0.0125)$ & $(0.0154)$ & $(0.00883)$ & $(0.00942)$ & $(0.0110)$ & $(0.0128)$ \\
\hline Property Right & $0.0425 * * *$ & $0.0404 * * *$ & $0.0403 * * *$ & $0.0345 * * *$ & -0.00520 & -0.00640 & -0.0110 & -0.00647 \\
\hline (Borrower) & $(0.00801)$ & $(0.00828)$ & $(0.0100)$ & $(0.0115)$ & $(0.00700)$ & $(0.00732)$ & $(0.00861)$ & $(0.00999)$ \\
\hline Real GDP Growth & 0.00175 & 0.00150 & 0.00220 & 0.00172 & -0.000962 & -0.000898 & -0.000814 & 0.000348 \\
\hline (Lender) & $(0.00107)$ & $(0.00111)$ & $(0.00134)$ & $(0.00147)$ & $(0.000967)$ & $(0.00100)$ & $(0.00119)$ & $(0.00139)$ \\
\hline Real GDP Growth & $0.00333 * * *$ & $0.00346^{* * *}$ & $0.00635^{* * *}$ & $0.00791 * * *$ & $0.00145^{* *}$ & $0.00139 * *$ & $0.00194 * *$ & $0.00227 * *$ \\
\hline (Borrower) & $(0.000744)$ & $(0.000774)$ & $(0.00108)$ & $(0.00127)$ & $(0.000630)$ & $(0.000648)$ & (0.000909) & $(0.00106)$ \\
\hline Credit to GDP & $0.000690^{* * *}$ & $0.000602 * * *$ & $0.000664 * * *$ & $0.000475^{*}$ & $0.000526^{* * *}$ & $0.000571 * * *$ & $0.000615^{* *}$ & $0.00112 * * *$ \\
\hline (Lender) & $(0.000207)$ & $(0.000211)$ & $(0.000252)$ & $(0.000274)$ & $(0.000193)$ & $(0.000201)$ & $(0.000240)$ & $(0.000271)$ \\
\hline Credit to GDP & $0.000581 * * *$ & $0.000632 * * *$ & $0.000713^{* * *}$ & $0.000778 * * *$ & $0.000828 * * *$ & $0.000830 * * *$ & $0.00100 * * *$ & $0.000885^{* * *}$ \\
\hline (Borrower) & $(0.000187)$ & $(0.000191)$ & $(0.000223)$ & $(0.000253)$ & $(0.000173)$ & $(0.000178)$ & $(0.000209)$ & $(0.000224)$ \\
\hline \multirow[t]{2}{*}{ Log Distance } & $-0.0541 * * *$ & $-0.0561 * * *$ & $-0.0532 * * *$ & $-0.0532 * * *$ & $-0.0386 * * *$ & $-0.0396 * * *$ & $-0.0334 * * *$ & $-0.0340 * * *$ \\
\hline & $(0.00535)$ & $(0.00544)$ & $(0.00609)$ & $(0.00652)$ & $(0.00637)$ & $(0.00654)$ & $(0.00775)$ & $(0.00838)$ \\
\hline \multirow[t]{2}{*}{ Common Language } & $0.0700 * * *$ & $0.0657 * * *$ & $0.0652 * * *$ & $0.0609 * * *$ & $0.0463 * * *$ & $0.0449 * * *$ & $0.0441 * * *$ & $0.0401 * * *$ \\
\hline & $(0.0116)$ & $(0.0120)$ & $(0.0140)$ & $(0.0149)$ & $(0.0106)$ & $(0.0111)$ & $(0.0129)$ & $(0.0131)$ \\
\hline \multirow[t]{2}{*}{ Overhead (inst.) } & $-0.0480 * * *$ & $-0.0478 * * *$ & $-0.0537 * * *$ & $-0.0410 *$ & -0.0252 & -0.0260 & -0.0303 & -0.0185 \\
\hline & $(0.0147)$ & $(0.0153)$ & $(0.0184)$ & $(0.0210)$ & $(0.0167)$ & $(0.0173)$ & $(0.0209)$ & $(0.0230)$ \\
\hline \multirow[t]{2}{*}{ Free Trade Agreement (inst.) } & & & & & $0.0187^{*}$ & $0.0196^{*}$ & $0.0385 * * *$ & $0.0385 * * *$ \\
\hline & & & & & $(0.0103)$ & $(0.0106)$ & $(0.0127)$ & $(0.0141)$ \\
\hline \multirow[t]{2}{*}{ High Time (inst.) } & & & & & -0.000933 & -0.000234 & -0.00155 & -0.00520 \\
\hline & & & & & $(0.00933)$ & $(0.00964)$ & $(0.0117)$ & $(0.0131)$ \\
\hline \multirow[t]{2}{*}{ High Cost (inst.) } & & & & & -0.00991 & -0.00886 & -0.0150 & 0.000726 \\
\hline & & & & & $(0.0163)$ & $(0.0168)$ & $(0.0215)$ & $(0.0229)$ \\
\hline $\mathrm{N}$ & 33314 & 31997 & 24299 & 19998 & 24783 & 24070 & 19246 & 15973 \\
\hline Pseudo-R2 & 0.188 & 0.184 & 0.154 & 0.154 & 0.243 & 0.238 & 0.218 & 0.225 \\
\hline
\end{tabular}

Table 3: Macroprudential policy, capital control and cross-border lending - first stage overall estimates

Note: Table 3 reports the first-stage (Probit) estimation results using overall MPM and CCM as independent variables. "Gravity" refers to the specification with no regulatory variables. "All" refers to the joint estimation controlling for overall MPM, CCM and non-core activity restrictions. Average marginal effects are reported. Standard errors are clustered at country pair level. Lender / borrower / year fixed effects are included. Dependent variables are binary indicators of direct cross-border / local affiliate connections. 


\begin{tabular}{|c|c|c|c|c|c|c|c|c|}
\hline & \multicolumn{4}{|c|}{ Direct Cross-Border } & \multicolumn{4}{|c|}{ Local Affiliate } \\
\hline & (1) ${ }^{\text {Gravity }}$ & (2) ${ }^{\text {MPM }}$ & (3) ${ }^{\mathrm{CCM}}$ & (4) ${ }^{\text {All }}$ & $\begin{array}{l}\text { Gravity } \\
\text { (5) }\end{array}$ & $(6)^{\text {MPM }}$ & ${ }_{(7)}^{\mathrm{CCM}}$ & $(8)^{\text {All }}$ \\
\hline Overall macroprudential index & & $0.0985 * *$ & & $-0.119^{*}$ & & 0.0778 & & $0.279^{* * *}$ \\
\hline (Lender) & & $(0.0395)$ & & $(0.0702)$ & & $(0.0889)$ & & $(0.106)$ \\
\hline Overall macroprudential index & & $0.0762 * *$ & & $0.151 * * *$ & & -0.0476 & & -0.0362 \\
\hline (Borrower) & & $(0.0358)$ & & $(0.0463)$ & & $(0.0772)$ & & $(0.0861)$ \\
\hline $\begin{array}{l}\text { Overall outflow restriction } \\
\text { (Lender) }\end{array}$ & & & $\begin{array}{l}0.447 * \\
(0.259)\end{array}$ & $\begin{array}{l}-0.115 \\
(0.324)\end{array}$ & & & $\begin{array}{l}1.417^{*} \\
(0.773)\end{array}$ & $\begin{array}{l}2.532 * * * \\
(0.834)\end{array}$ \\
\hline Overall inflow restriction & & & -0.00426 & 0.143 & & & 0.568 & 1.280 \\
\hline (Borrower) & & & $(0.242)$ & $(0.279)$ & & & $(0.847)$ & $(0.924)$ \\
\hline Activity restriction (Lender) & & & & $\begin{array}{l}0.208 * * * \\
(0.0435)\end{array}$ & & & & $\begin{array}{l}0.192 \\
(0.125)\end{array}$ \\
\hline Activity restriction (Borrower) & & & & $\begin{array}{l}0.00427 \\
(0.0230)\end{array}$ & & & & $\begin{array}{l}0.0745 \\
(0.0920)\end{array}$ \\
\hline Interest Rate (Lagged) & $0.0331 *$ & $0.0320^{*}$ & $0.0551 * * *$ & 0.0139 & 0.0798 & 0.0865 & $0.105^{* *}$ & -0.0551 \\
\hline (Lender) & $(0.0187)$ & $(0.0187)$ & $(0.0190)$ & $(0.0259)$ & $(0.0553)$ & $(0.0566)$ & $(0.0529)$ & $(0.0669)$ \\
\hline Interest Rate (Lagged) & 0.00963 & 0.00872 & 0.00831 & $0.0285^{* *}$ & -0.00277 & -0.00454 & 0.0180 & 0.0157 \\
\hline (Borrower) & $(0.00839)$ & $(0.00835)$ & $(0.0110)$ & $(0.0130)$ & $(0.0403)$ & $(0.0402)$ & $(0.0434)$ & $(0.0533)$ \\
\hline Property Right & $0.529 * * *$ & $0.592 * * *$ & $0.497 * * *$ & $0.214 * *$ & $0.809 * * *$ & $0.858 * * *$ & $0.903 * * *$ & $0.906^{* * *}$ \\
\hline (Lender) & $(0.0688)$ & $(0.0711)$ & $(0.0728)$ & $(0.0918)$ & $(0.271)$ & $(0.269)$ & $(0.259)$ & $(0.327)$ \\
\hline Property Right & $0.529 * * *$ & $0.586 * * *$ & $0.484 * * *$ & $0.356 * * *$ & -0.124 & -0.154 & -0.122 & -0.183 \\
\hline (Borrower) & $(0.0718)$ & $(0.0659)$ & $(0.0728)$ & $(0.0915)$ & $(0.187)$ & $(0.189)$ & $(0.191)$ & $(0.229)$ \\
\hline Real GDP Growth & $0.0359 * * *$ & $0.0374 * * *$ & $0.0399 * * *$ & $0.0314 * *$ & $-0.0454 *$ & $-0.0497 * *$ & $-0.0422 *$ & -0.0276 \\
\hline (Lender) & $(0.0103)$ & $(0.0103)$ & $(0.0110)$ & $(0.0127)$ & $(0.0243)$ & $(0.0241)$ & $(0.0238)$ & $(0.0270)$ \\
\hline Real GDP Growth & 0.00207 & 0.00899 & -0.00589 & $-0.0427 * *$ & 0.0122 & 0.0154 & 0.0276 & $0.0483 *$ \\
\hline (Borrower) & $(0.00831)$ & $(0.00818)$ & $(0.0122)$ & $(0.0175)$ & $(0.0213)$ & $(0.0207)$ & $(0.0227)$ & $(0.0266)$ \\
\hline Credit to GDP & $0.0183^{* * *}$ & $0.0189 * * *$ & $0.0197 * * *$ & $0.0188 * * *$ & 0.00236 & 0.00163 & 0.00558 & 0.0141 \\
\hline (Lender) & $(0.00218)$ & $(0.00212)$ & $(0.00229)$ & $(0.00244)$ & $(0.00721)$ & $(0.00729)$ & $(0.00653)$ & $(0.00936)$ \\
\hline Credit to GDP & $0.00802^{* * *}$ & $0.00880 * * *$ & $0.00670 * * *$ & 0.00109 & 0.0134 & $0.0146^{*}$ & $0.0189 * *$ & $0.0271 * * *$ \\
\hline (Borrower) & $(0.00174)$ & $(0.00173)$ & $(0.00187)$ & $(0.00224)$ & $(0.00843)$ & $(0.00804)$ & $(0.00748)$ & $(0.00736)$ \\
\hline Log Distance & $-0.842 * * *$ & $-0.968 * * *$ & $-0.757 * * *$ & $-0.539 * * *$ & $-0.954 * * *$ & $-0.995 * * *$ & $-1.137 * * *$ & $-1.577 * * *$ \\
\hline & $(0.0832)$ & $(0.0804)$ & $(0.0813)$ & $(0.0989)$ & $(0.354)$ & $(0.341)$ & $(0.276)$ & $(0.361)$ \\
\hline Common Language & $0.605 * * *$ & $0.735 * * *$ & $0.552 * * *$ & $0.259 *$ & 0.764 & $0.820^{*}$ & $1.057 * * *$ & $1.511^{* * *}$ \\
\hline & $(0.126)$ & $(0.116)$ & $(0.123)$ & $(0.140)$ & $(0.498)$ & $(0.466)$ & $(0.380)$ & $(0.388)$ \\
\hline$\delta$ & $1.845^{* * *}$ & $1.306^{* * *}$ & $1.763^{* * *}$ & $2.374 * * *$ & $7.052 * * *$ & $7.012 * * *$ & $5.939 * * *$ & $4.628^{* *}$ \\
\hline & $(0.214)$ & $(0.122)$ & $(0.217)$ & $(0.399)$ & $(1.420)$ & (1.407) & $(1.393)$ & $(1.883)$ \\
\hline$\beta$ & 0.642 & $1.329 * * *$ & 0.161 & $-1.826 * *$ & 0.419 & 0.578 & 1.173 & $2.997 * *$ \\
\hline & $(0.504)$ & $(0.467)$ & $(0.565)$ & $(0.713)$ & $(1.520)$ & $(1.481)$ & $(1.302)$ & $(1.369)$ \\
\hline$\sigma$ & $1.643^{* * *}$ & $1.645^{* * *}$ & $1.602 * * *$ & $1.586 * * *$ & $2.394 * * *$ & $2.397 * * *$ & $2.378 * * *$ & $2.379 * * *$ \\
\hline & $(0.0168)$ & $(0.0170)$ & $(0.0175)$ & $(0.0181)$ & $(0.0462)$ & $(0.0462)$ & $(0.0472)$ & $(0.0489)$ \\
\hline $\mathrm{N}$ & 9170 & 9032 & 7924 & 6754 & 2952 & 2942 & 2755 & 2379 \\
\hline
\end{tabular}

Table 4: Macroprudential policy, capital control and cross-border lending - second stage overall estimates

Note: Table 4 reports the second-stage (maximum likelihood) estimation results using overall MPM and CCM as independent variables. "Gravity" refers to the specification with no regulatory variables. "All" refers to the joint estimation controlling for overall MPM, CCM and non-core activity restrictions. Structural parameters follow the notation introduced in Section 2. Standard errors are clustered at country pair level. Lender / borrower / year fixed effects are included. Dependent variables are direct cross-border / local affiliate flows. 


\begin{tabular}{|c|c|c|c|}
\hline & & Direct Cross-Border & Local Affiliate \\
\hline \multirow{5}{*}{ Overall } & \multirow{2}{*}{ Lender } & $-0.119^{*}$ & $0.279 * * *$ \\
\hline & & $(0.0702)$ & $(0.106)$ \\
\hline & \multirow{2}{*}{ Borrower } & $0.151 * * *$ & -0.0362 \\
\hline & & $(0.0463)$ & $(0.0861)$ \\
\hline & $\mathrm{N}$ & 6754 & 2379 \\
\hline \multirow{5}{*}{ LTV } & \multirow{2}{*}{ Lender } & -0.163 & -0.190 \\
\hline & & $(0.211)$ & $(0.292)$ \\
\hline & \multirow{2}{*}{ Borrower } & 0.146 & 0.111 \\
\hline & & $(0.107)$ & $(0.249)$ \\
\hline & $\mathrm{N}$ & 6754 & 2379 \\
\hline \multirow{5}{*}{ Leverage Ratio } & \multirow{2}{*}{ Lender } & $-0.907 * * *$ & 0.683 \\
\hline & & $(0.300)$ & $(0.460)$ \\
\hline & \multirow{2}{*}{ Borrower } & $0.487 * * *$ & 0.400 \\
\hline & & $(0.160)$ & $(0.320)$ \\
\hline & $\mathrm{N}$ & 6754 & 2379 \\
\hline \multirow{5}{*}{ Interbank Exposure } & \multirow{2}{*}{ Lender } & -0.204 & 0.713 \\
\hline & & $(0.219)$ & $(0.448)$ \\
\hline & \multirow{2}{*}{ Borrower } & $0.396 * * *$ & -0.0256 \\
\hline & & $(0.139)$ & $(0.282)$ \\
\hline & $\mathrm{N}$ & 6754 & 2379 \\
\hline \multirow{5}{*}{ Foreign Currency Loan } & \multirow{2}{*}{ Lender } & -0.0404 & 0.548 \\
\hline & & $(0.295)$ & $(0.669)$ \\
\hline & \multirow{2}{*}{ Borrower } & $0.493 * * *$ & -0.326 \\
\hline & & $(0.184)$ & $(0.328)$ \\
\hline & $\mathrm{N}$ & 6754 & 2379 \\
\hline
\end{tabular}

Table 5: Macroprudential policy and cross-border banking - second-stage specific estimates

Note: Table 5 report the effect of various macroprudential policy measures (MPM) on direct crossborder and local affiliate banking flows. Each pair of home/host regulatory measures is added separately into regression specifications in Section 3, controlling for other regulations. For MPM, overall capital outflow / inflow restrictions, monetary policy and bank non-core activity restrictions are added as additional controls along with gravity variables. Only the coefficients of interest are reported. Second-stage ML estimates are reported, along with standard errors clustered at countrypair level. Dependent variables are direct cross-border / local affiliate flows. 


\begin{tabular}{|c|c|c|c|c|c|c|c|c|c|c|}
\hline & \multicolumn{2}{|c|}{ Baseline } & \multicolumn{4}{|c|}{ Weighted Inflow to Neighbors } & \multicolumn{4}{|c|}{ Change in Credit to GDP } \\
\hline & Direct Cross-Border & Local Affiliate & Direct $\mathrm{Cl}_{1}$ & ss-Border & Local & ffiliate & Direct $\mathrm{Cr}$ & ss-Border & Local & Affiliate \\
\hline \multirow{2}{*}{ Overall } & $0.151 * * *$ & -0.0362 & $0.153 * * *$ & $0.153 * * *$ & -0.0383 & -0.0347 & $0.279 * * *$ & $0.279 * * *$ & -0.00801 & 0.0117 \\
\hline & $(0.0463)$ & $(0.0861)$ & $(0.0465)$ & $(0.0465)$ & $(0.0857)$ & $(0.0858)$ & $(0.0637)$ & $(0.0637)$ & $(0.0874)$ & $(0.0891)$ \\
\hline \multirow{2}{*}{ Additional Variable } & & & -0.000441 & -0.000756 & $0.0866^{* *}$ & $0.142 * *$ & $-0.0136^{* *}$ & $-0.0135^{*}$ & $0.0339 * * *$ & $0.0456^{* * *}$ \\
\hline & & & $(0.000778)$ & $(0.00109)$ & $(0.0426)$ & $(0.0674)$ & $(0.00622)$ & $(0.00687)$ & $(0.0115)$ & $(0.0140)$ \\
\hline \multirow{2}{*}{ Interaction } & & & & 0.000165 & & -0.0260 & & -0.0000527 & & -0.00399 \\
\hline & & & & $(0.000433)$ & & $(0.0209)$ & & $(0.00119)$ & & $(0.00334)$ \\
\hline $\mathrm{N}$ & 6754 & 2379 & 6754 & 6754 & 2379 & 2379 & 6754 & 6754 & 2379 & 2379 \\
\hline \multirow{2}{*}{ LTV } & 0.146 & 0.111 & 0.147 & 0.134 & 0.101 & 0.102 & $0.285^{* *}$ & $0.279 * *$ & 0.125 & 0.135 \\
\hline & $(0.107)$ & $(0.249)$ & $(0.107)$ & $(0.107)$ & $(0.248)$ & $(0.248)$ & $(0.117)$ & $(0.117)$ & $(0.252)$ & $(0.254)$ \\
\hline \multirow{2}{*}{ Additional Variable } & & & -0.000747 & -0.000825 & $0.0904 * *$ & $0.0962 * *$ & $-0.0147 * *$ & $-0.0154 * *$ & $0.0340 * * *$ & $0.0351 * * *$ \\
\hline & & & $(0.000804)$ & $(0.000801)$ & $(0.0429)$ & $(0.0441)$ & $(0.00581)$ & $(0.00605)$ & $(0.0117)$ & $(0.0131)$ \\
\hline \multirow{2}{*}{ Interaction } & & & & $0.0150 * *$ & & -0.0648 & & 0.00202 & & -0.00351 \\
\hline & & & & $(0.00703)$ & & $(0.0841)$ & & $(0.00577)$ & & $(0.0153)$ \\
\hline $\mathrm{N}$ & 6754 & 2379 & 6754 & 6754 & 2379 & 2379 & 6754 & 6754 & 2379 & 2379 \\
\hline \multirow{2}{*}{ Leverage Ratio } & $0.487 * * *$ & 0.400 & $0.490 * * *$ & $0.513 * * *$ & 0.397 & 0.410 & $0.690 * * *$ & $0.781^{* * *}$ & 0.484 & $0.660^{*}$ \\
\hline & $(0.160)$ & $(0.320)$ & $(0.160)$ & $(0.163)$ & $(0.319)$ & $(0.318)$ & $(0.169)$ & $(0.180)$ & $(0.322)$ & $(0.339)$ \\
\hline \multirow{2}{*}{ Additional Variable } & & & -0.000464 & -0.000493 & $0.0895 * *$ & $0.0896 * *$ & $-0.0185^{* *}$ & $-0.0164 * *$ & $0.0334 * * *$ & $0.0403 * * *$ \\
\hline & & & $(0.000786)$ & $(0.000786)$ & $(0.0427)$ & $(0.0427)$ & $(0.00718)$ & $(0.00721)$ & $(0.0114)$ & $(0.0109)$ \\
\hline \multirow{2}{*}{ Interaction } & & & & 0.0151 & & 0.315 & & $-0.0134 * *$ & & -0.0287 \\
\hline & & & & $(0.0206)$ & & $(0.337)$ & & $(0.00678)$ & & $(0.0182)$ \\
\hline $\mathrm{N}$ & 6754 & 2379 & 6754 & 6754 & 2379 & 2379 & 6754 & 6754 & 2379 & 2379 \\
\hline \multirow{2}{*}{ Interbank Exposure } & $0.396^{* * *}$ & -0.0256 & $0.398 * * *$ & $0.397 * * *$ & $\begin{array}{l}-0.0399 \\
\end{array}$ & $\begin{array}{l}-0.0463 \\
\end{array}$ & $0.613 * * *$ & $0.617^{* * *}$ & 0.111 & 0.193 \\
\hline & $(0.139)$ & $(0.282)$ & $(0.139)$ & $(0.139)$ & $(0.280)$ & $(0.279)$ & $(0.155)$ & $(0.155)$ & $(0.276)$ & $(0.279)$ \\
\hline \multirow{2}{*}{ Additional Variable } & & & -0.000431 & -0.00115 & $0.0910 * *$ & $0.105^{*}$ & $-0.0138 * *$ & $-0.0131 * *$ & $0.0351 * * *$ & $0.0475 * * *$ \\
\hline & & & $(0.000776)$ & $(0.00105)$ & $(0.0427)$ & $(0.0543)$ & $(0.00621)$ & $(0.00631)$ & $(0.0116)$ & $(0.0115)$ \\
\hline \multirow{2}{*}{ Interaction } & & & & 0.00115 & & -0.0312 & & -0.00269 & & $-0.0396 * * *$ \\
\hline & & & & $(0.00131)$ & & $(0.0583)$ & & $(0.00631)$ & & $(0.0139)$ \\
\hline $\mathrm{N}$ & 6754 & 2379 & 6754 & 6754 & 2379 & 2379 & 6754 & 6754 & 2379 & 2379 \\
\hline \multirow{2}{*}{ Foreign Currency Loan } & $0.493 * * *$ & -0.326 & $0.503 * * *$ & $0.496 * * *$ & -0.324 & -0.338 & $0.797 * * *$ & $0.784 * * *$ & -0.482 & -0.537 \\
\hline & $(0.184)$ & $(0.328)$ & $(0.185)$ & $(0.183)$ & $(0.326)$ & $(0.325)$ & $(0.182)$ & $(0.179)$ & $(0.340)$ & $(0.343)$ \\
\hline \multirow{2}{*}{ Additional Variable } & & & $-0.00210 * *$ & $-0.00210^{* *}$ & $0.0884 * *$ & $0.0882 * *$ & $-0.0260 * * *$ & $-0.0268 * * *$ & $0.0349 * * *$ & $0.0327 * *$ \\
\hline & & & $(0.000944)$ & $(0.000946)$ & $(0.0427)$ & $(0.0427)$ & $(0.00547)$ & $(0.00574)$ & $(0.0117)$ & $(0.0127)$ \\
\hline & & & & 0.00803 & & 0.0526 & & 0.00310 & & 0.00845 \\
\hline Interaction & & & & $(0.0191)$ & & $(0.176)$ & & $(0.00558)$ & & $(0.0154)$ \\
\hline $\mathrm{N}$ & 6754 & 2379 & 6754 & 6754 & 2379 & 2379 & 6754 & 6754 & 2379 & 2379 \\
\hline
\end{tabular}

Table 6: Borrowers' macroprudential policy and cross-border banking: Interaction with credit cycles

Note: Table 6 reports second-stage regression coefficients of borrower's macroprudential policy measures and their interaction with credit cycle proxies ("additional variable"). For each borrower, "weighted inflow to neighbors" is the distance-GDP-weighted average flow to the borrower's regional peers. "Change in Credit to GDP" is the year-over-year change in credit to GDP ratio. Only the coefficients of interest are reported. Second-stage ML estimates are reported, along with standard errors clustered at country-pair level. 


\begin{tabular}{|c|c|c|c|c|c|}
\hline & & \multicolumn{2}{|c|}{ AE Borrower Sample } & \multicolumn{2}{|c|}{ EMDE Borrower Sample } \\
\hline & & Direct Cross-Border & Local Affiliate & Direct Cross-Border & Local Affiliate \\
\hline \multirow{5}{*}{ Overall } & \multirow{2}{*}{ Lender } & -0.0412 & $0.232 *$ & $-0.377 * * *$ & 0.264 \\
\hline & & $(0.0763)$ & $(0.132)$ & $(0.113)$ & $(0.162)$ \\
\hline & \multirow{2}{*}{ Borrower } & $0.141^{* *}$ & -0.0986 & $0.107^{*}$ & 0.0697 \\
\hline & & $(0.0573)$ & $(0.0987)$ & $(0.0558)$ & $(0.190)$ \\
\hline & $\mathrm{N}$ & 3325 & 1419 & 3429 & 960 \\
\hline \multirow{5}{*}{ LTV } & \multirow{2}{*}{ Lender } & 0.180 & -0.103 & -0.285 & 0.0432 \\
\hline & & $(0.215)$ & $(0.365)$ & $(0.220)$ & $(0.762)$ \\
\hline & \multirow{2}{*}{ Borrower } & 0.0625 & 0.0641 & 0.0607 & 0.136 \\
\hline & & $(0.131)$ & $(0.335)$ & $(0.146)$ & $(0.513)$ \\
\hline & $\mathrm{N}$ & 3325 & 1419 & 3429 & 960 \\
\hline \multirow{5}{*}{ Leverage Ratio } & \multirow{2}{*}{ Lender } & $-0.800 * *$ & $1.152 * *$ & $-1.309 * * *$ & 0.174 \\
\hline & & $(0.353)$ & $(0.470)$ & $(0.427)$ & $(1.144)$ \\
\hline & \multirow{2}{*}{ Borrower } & 0.352 & -0.184 & $0.460 * *$ & -0.890 \\
\hline & & $(0.281)$ & $(0.390)$ & $(0.190)$ & $(1.803)$ \\
\hline & $\mathrm{N}$ & 3325 & 1419 & 3429 & 960 \\
\hline \multirow{5}{*}{ Interbank Exposure } & \multirow{2}{*}{ Lender } & -0.0937 & $0.968^{* *}$ & $-0.827 * *$ & 0.583 \\
\hline & & $(0.205)$ & $(0.463)$ & $(0.402)$ & $(0.819)$ \\
\hline & \multirow{2}{*}{ Borrower } & $0.403 * *$ & -0.0364 & 0.0901 & -0.703 \\
\hline & & $(0.164)$ & $(0.327)$ & $(0.237)$ & $(0.909)$ \\
\hline & $\mathrm{N}$ & 3325 & 1419 & 3429 & 960 \\
\hline \multirow{5}{*}{ Foreign Currency Loan } & \multirow{2}{*}{ Lender } & 0.676 & -0.509 & $-1.168 * * *$ & 0.630 \\
\hline & & $(0.464)$ & $(0.959)$ & $(0.358)$ & $(0.749)$ \\
\hline & \multirow{2}{*}{ Borrower } & 0.00613 & $-0.868^{* *}$ & $0.397^{*}$ & -0.293 \\
\hline & & $(0.202)$ & $(0.438)$ & $(0.217)$ & $(0.459)$ \\
\hline & $\mathrm{N}$ & 3325 & 1419 & 3429 & 960 \\
\hline
\end{tabular}

Table 7: Macroprudential policy and cross-border banking - second-stage specific estimates, AE/EMDE breakdown

Note: Table 7 reports the second-stage ML estimation results of the effect of macroprudential policy on cross-border banking. Samples are split into advanced economy (AE) borrowers / emerging and development economy (EMDE) borrowers according to World Economic Outlook (WEO) definition. Lender sample is held constant. Only the coefficients of interest are reported. Second-stage ML estimates are reported, along with standard errors clustered at country-pair level. Dependent variables are direct cross-border / local affiliate flows. 


\begin{tabular}{|c|c|c|c|}
\hline & & Direct Cross-Border & Local Affiliate \\
\hline \multirow{4}{*}{ Overall } & Lender (Outflow) & $\begin{array}{l}-0.116 \\
(0.324)\end{array}$ & $\begin{array}{l}2.532 * * * \\
(0.834)\end{array}$ \\
\hline & \multirow{2}{*}{ Borrower (Inflow) } & 0.143 & 1.280 \\
\hline & & $(0.279)$ & $(0.924)$ \\
\hline & $\mathrm{N}$ & 6754 & 2379 \\
\hline \multirow{5}{*}{ Bond } & \multirow{2}{*}{ Lender (Outflow) } & 0.262 & $1.600 * * *$ \\
\hline & & $(0.165)$ & $(0.587)$ \\
\hline & \multirow{2}{*}{ Borrower (Inflow) } & -0.201 & 0.690 \\
\hline & & $(0.189)$ & $(0.677)$ \\
\hline & $\mathrm{N}$ & 6754 & 2379 \\
\hline \multirow{5}{*}{ Commercial Credit } & \multirow{2}{*}{ Lender (Outflow) } & $0.520 * *$ & 0.691 \\
\hline & & $(0.252)$ & $(0.665)$ \\
\hline & \multirow{2}{*}{ Borrower (Inflow) } & -0.0391 & 0.381 \\
\hline & & $(0.128)$ & $(0.318)$ \\
\hline & $\mathrm{N}$ & 6734 & 2375 \\
\hline \multirow{5}{*}{ Foreign Credit } & \multirow{2}{*}{ Lender (Outflow) } & $0.255^{* *}$ & 0.575 \\
\hline & & $(0.125)$ & $(0.351)$ \\
\hline & \multirow{2}{*}{ Borrower (Inflow) } & 0.0843 & $0.839 * *$ \\
\hline & & $(0.106)$ & $(0.424)$ \\
\hline & $\mathrm{N}$ & 6734 & 2375 \\
\hline
\end{tabular}

Table 8: Capital control and cross-border banking - second-stage specific estimates

Note: Table 8 report the effect of various capital control measures (CCM) on direct cross-border and local affiliate banking flows. Each pair of home/host regulatory measures is added separately into regression specifications, controlling for other regulations. For CCM, overall macroprudential policy, monetary policy and bank non-core activity restrictions are added as additional controls. Only the coefficients of interest are reported. Second-stage ML estimates are reported, along with standard errors clustered at country-pair level. Dependent variables are direct cross-border / local affiliate flows. 


\begin{tabular}{|c|c|c|c|c|c|}
\hline & & \multicolumn{2}{|c|}{ AE Borrowers } & \multicolumn{2}{|c|}{ EMDE Borrowers } \\
\hline & & Direct Cross-Border & Local Affiliate & Direct Cross-Border & Local Affiliate \\
\hline \multirow{5}{*}{ Overall } & & -0.462 & $2.895 * * *$ & 0.218 & 1.321 \\
\hline & Lender (Outflow) & $(0.396)$ & $(0.844)$ & $(0.473)$ & $(1.404)$ \\
\hline & & 0.628 & 1.909 & 0.506 & 0.220 \\
\hline & Borrower (Inflow) & $(0.588)$ & $(1.595)$ & $(0.320)$ & (1.992) \\
\hline & $\mathrm{N}$ & 3325 & 1419 & 3429 & 960 \\
\hline \multirow{5}{*}{ Bond } & & -0.00381 & $1.515^{* * *}$ & $0.554 * *$ & 1.242 \\
\hline & Lender (Uuttlow) & $(0.207)$ & $(0.558)$ & $(0.253)$ & $(1.285)$ \\
\hline & & -0.0198 & 1.133 & -0.334 & -0.288 \\
\hline & Borrower (Inflow) & $(0.447)$ & $(0.992)$ & $(0.206)$ & $(2.063)$ \\
\hline & $\mathrm{N}$ & 3325 & 1419 & 3429 & 960 \\
\hline \multirow{5}{*}{ Commercial Credit } & & $1.003 * *$ & 0.673 & 0.415 & -2.602 \\
\hline & Lender (Outflow) & $(0.394)$ & $(0.447)$ & $(0.352)$ & $(1.835)$ \\
\hline & & $1.963 * *$ & 2.091 & 0.108 & $0.554 *$ \\
\hline & Borrower (Inflow) & $(0.925)$ & $(1.842)$ & $(0.124)$ & $(0.323)$ \\
\hline & $\mathrm{N}$ & 3311 & 1416 & 3423 & 959 \\
\hline \multirow{5}{*}{ Foreign Credit } & Lender (Outflow) & 0.200 & $0.661 * *$ & $0.307^{*}$ & 0.317 \\
\hline & Lender (vutrow) & $(0.191)$ & $(0.309)$ & $(0.160)$ & $(0.906)$ \\
\hline & & 0.256 & -1.511 & 0.133 & 0.465 \\
\hline & Borrower (Inflow) & $(0.559)$ & $(1.720)$ & $(0.105)$ & $(0.711)$ \\
\hline & $\mathrm{N}$ & 3311 & 1416 & 3423 & 959 \\
\hline
\end{tabular}

Table 9: Capital control measures and cross-border banking - second-stage specific estimates, AE/EM breakdown

Note: Table 9 reports the second-stage ML estimation results of the effect of capital control measures on cross-border banking. Samples are split into advanced economy (AE) borrowers / emerging and development economy (EMDE) borrowers according to World Economic Outlook (WEO) definition. Lender sample is held constant. Only the coefficients of interest are reported. Second-stage ML estimates are reported, along with standard errors clustered at country-pair level. 


\begin{tabular}{|c|c|c|c|}
\hline Macroprudential Policy & & Direct Cross-Border & Local Affiliate \\
\hline \multirow{5}{*}{ Overall } & \multirow{2}{*}{ Lender } & $-0.136^{*}$ & $0.296 * * *$ \\
\hline & & $(0.0773)$ & $(0.107)$ \\
\hline & \multirow{2}{*}{ Borrower } & $0.171 * * *$ & -0.0156 \\
\hline & & $(0.0483)$ & $(0.0873)$ \\
\hline & $\mathrm{N}$ & 6502 & 2292 \\
\hline \multirow{5}{*}{ LTV } & \multirow{2}{*}{ Lender } & -0.275 & -0.123 \\
\hline & & $(0.242)$ & $(0.289)$ \\
\hline & \multirow{2}{*}{ Borrower } & 0.161 & 0.142 \\
\hline & & $(0.109)$ & $(0.251)$ \\
\hline & $\mathrm{N}$ & 6502 & 2292 \\
\hline \multirow{5}{*}{ Leverage Ratio } & \multirow{2}{*}{ Lender } & $-1.073 * * *$ & 0.655 \\
\hline & & $(0.342)$ & $(0.466)$ \\
\hline & \multirow{2}{*}{ Borrower } & $0.557 * * *$ & 0.386 \\
\hline & & $(0.159)$ & $(0.320)$ \\
\hline & $\mathrm{N}$ & 6502 & 2292 \\
\hline \multirow{5}{*}{ Interbank Exposure } & \multirow{2}{*}{ Lender } & -0.298 & $0.831 *$ \\
\hline & & $(0.240)$ & $(0.448)$ \\
\hline & \multirow{2}{*}{ Borrower } & $0.421 * * *$ & -0.143 \\
\hline & & $(0.143)$ & $(0.290)$ \\
\hline & $\mathrm{N}$ & 6502 & 2292 \\
\hline \multirow{5}{*}{ Foreign Currency Loan } & \multirow{2}{*}{ Lender } & 0.362 & 0.563 \\
\hline & & $(0.344)$ & $(0.675)$ \\
\hline & \multirow{2}{*}{ Borrower } & $0.604 * * *$ & -0.156 \\
\hline & & $(0.196)$ & $(0.355)$ \\
\hline & $\mathrm{N}$ & 6502 & 2292 \\
\hline \multicolumn{4}{|l|}{ Capital Control Measures } \\
\hline \multirow{5}{*}{ Overall } & \multirow{2}{*}{ Lender (Outflow) } & -0.277 & $3.043 * * *$ \\
\hline & & $(0.333)$ & $(0.858)$ \\
\hline & \multirow{2}{*}{ Borrower (Inflow) } & 0.137 & 1.316 \\
\hline & & $(0.277)$ & $(0.911)$ \\
\hline & $\mathrm{N}$ & 6502 & 2292 \\
\hline \multirow{5}{*}{ Bond } & \multirow{2}{*}{ Lender (Outflow) } & 0.161 & $1.910 * * *$ \\
\hline & & $(0.167)$ & $(0.582)$ \\
\hline & \multirow{2}{*}{ Borrower (Inflow) } & -0.278 & 0.795 \\
\hline & & $(0.194)$ & $(0.682)$ \\
\hline & $\mathrm{N}$ & 6502 & 2292 \\
\hline \multirow{5}{*}{ Commercial Credit } & \multirow{2}{*}{ Lender (Outflow) } & $0.506^{* *}$ & 1.042 \\
\hline & & $(0.258)$ & $(0.676)$ \\
\hline & & 0.0249 & 0.380 \\
\hline & Borrower (Intlow) & $(0.126)$ & $(0.316)$ \\
\hline & $\mathrm{N}$ & 6482 & 2288 \\
\hline & & $0.268 * *$ & $0.724 * *$ \\
\hline & Lender (Outflow) & $(0.128)$ & $(0.342)$ \\
\hline Foreign Credit & & 0.104 & $0.823 *$ \\
\hline & Borrower (Inflow) & $(0.103)$ & $(0.421)$ \\
\hline & $\mathrm{N}$ & 6482 & 2288 \\
\hline
\end{tabular}

Table 10: MPM, CCM and cross-border banking: robustness to right censoring

Note: Table 10 reports the second-stage ML estimation results similar to Table 5 and 8 , except that the samples are right censored. Observations are dropped if the year-over-year growth rate of cross-border claims is above the 95th percentile. Standard errors are clustered at country-pair level. 


\begin{tabular}{|c|c|c|c|}
\hline Macroprudential Policy & & Direct Cross-Border & Local Affiliate \\
\hline \multirow{5}{*}{ Overall } & & $-0.214 * *$ & $0.453^{* * *}$ \\
\hline & Lender & $(0.0917)$ & $(0.151)$ \\
\hline & Rorrowar & $0.333 * * *$ & -0.0895 \\
\hline & Dorrower & $(0.0974)$ & $(0.136)$ \\
\hline & $\mathrm{N}$ & 2931 & 1047 \\
\hline \multirow{4}{*}{ LTV } & Lender & 0.188 & 0.487 \\
\hline & & $\begin{array}{l}(0.256) \\
0.354 *\end{array}$ & $\begin{array}{l}(0.526) \\
-0.0951\end{array}$ \\
\hline & Borrower & $(0.186)$ & $(0.544)$ \\
\hline & $\mathrm{N}$ & 2931 & 1047 \\
\hline \multirow{5}{*}{ Leverage Ratio } & Lender & $-1.584 * * *$ & 0.301 \\
\hline & Lender & $(0.429)$ & $(0.517)$ \\
\hline & Borrower & $0.634 * * *$ & 0.551 \\
\hline & Borrower & $(0.204)$ & $(0.405)$ \\
\hline & $\mathrm{N}$ & 2931 & 1047 \\
\hline \multirow{4}{*}{ Interbank Exposure } & Lender & $\begin{array}{l}-1.320 * * * \\
(0.486)\end{array}$ & $\begin{array}{l}1.798 * * * \\
(0.655)\end{array}$ \\
\hline & Dorroutar & 0.337 & 0.434 \\
\hline & DOHOWC & $(0.272)$ & $(0.751)$ \\
\hline & $\mathrm{N}$ & 2931 & 1047 \\
\hline \multirow{4}{*}{ Foreign Currency Loan } & Lender & $\begin{array}{l}-4.653 * * * \\
(1.165)\end{array}$ & $\begin{array}{l}-0.318 \\
(1.977)\end{array}$ \\
\hline & Rorrower & $0.721^{* *}$ & 0.138 \\
\hline & Borrower & $(0.323)$ & $(0.727)$ \\
\hline & $\mathrm{N}$ & 2931 & 1047 \\
\hline \multicolumn{4}{|l|}{ Capital Control Measures } \\
\hline \multirow{4}{*}{ Overall } & Lender (Outflow) & $2.471 * * *$ & 1.124 \\
\hline & & $(0.775)$ & $(1.062)$ \\
\hline & Borrower (Inflow) & $\begin{array}{l}0.757 \\
(0.688)\end{array}$ & $\begin{array}{l}-0.249 \\
(1.876)\end{array}$ \\
\hline & $\mathrm{N}$ & 2931 & 1047 \\
\hline \multirow{4}{*}{ Bond } & Lender (Outflow) & $2.522 * * *$ & 0.650 \\
\hline & & $\begin{array}{l}(0.589) \\
0.182\end{array}$ & $\begin{array}{l}0.815) \\
0.0248\end{array}$ \\
\hline & Borrower (Inflow) & $(0.292)$ & $(0.989)$ \\
\hline & $\mathrm{N}$ & 2931 & 1047 \\
\hline \multirow{5}{*}{ Commercial Credit } & Lender (Outflow) & 0.221 & 0.996 \\
\hline & & $(0.422)$ & $(0.646)$ \\
\hline & Borrower (Inflow) & $-0.759 * * *$ & -0.141 \\
\hline & & $(0.248)$ & $(0.643)$ \\
\hline & $\mathrm{N}$ & 2931 & 1047 \\
\hline \multirow{5}{*}{ Foreign Credit } & Lender (Outflow) & $0.711 * * *$ & 0.304 \\
\hline & & $(0.269)$ & $(0.396)$ \\
\hline & Borrower (Inflow) & 0.0787 & -1.817 \\
\hline & Borrower (IIIIOW) & $(0.381)$ & $(1.169)$ \\
\hline & $\mathrm{N}$ & 2931 & 1047 \\
\hline
\end{tabular}

Table 11: MPM, CCM and cross-border banking: 2011-2015 sample estimates

Note: Table 11 reports the second-stage ML estimation results similar to Table 5 and 8 , except that the samples are restricted to 2011-2015 only. Standard errors are clustered at country-pair level. 


\section{APPENDIX A.1. MICRO-FOUND THE EMPIRICAL FRAMEWORK AND COUNTERFACTUAL ANALYSIS}

In this section, we sketch the derivation of our empirical framework laid out in Section 2. For a full exposition, see Cerutti and Zhou (2018).

Country $j$ has $N_{j}$ banks, each of which could access a domestic loan market, risk-free asset market and a deposit market. In addition, each bank could choose to internationalize by engaging in direct cross-border lending and/or operating a local subsidiary in destination country $i$, by paying an upfront fixed cost and variable monitoring cost of loans. Each bank's problem at the intensive margin, when it makes direct cross-border lending (CB) and local affiliate lending (S), is

$$
\max _{L_{j}, L_{i j}^{C B}, L_{i j}^{S}, D, M} \Pi_{j}+\Pi_{i j}^{C B}+\Pi_{i j}^{S}+r_{f} M-r_{D}(D) D
$$

subject to the balance-sheet constraint

$$
E+D \geq L_{j}+L_{i j}^{C B}+L_{i j}^{S}+M
$$

In the above expressions, E, D, M refer to equities, deposits and risk-free assets (paying a riskfree rate $\left.r_{f}\right)$, respectively. For direct cross-border loan $\left(L_{i j}^{C B}\right)$ and local affiliate lending $\left(L_{i j}^{S}\right)$, the associated profit functions is, respectively:

$$
\begin{gathered}
\Pi_{i j}^{C B}=\tau_{i j}^{C B} r_{L_{i j}}\left(L_{i j}^{C B}\right) L_{i j}^{C B}-C_{j}(a) L_{i j}^{C B}-c_{j} f_{i j}^{C B} \\
\Pi_{i j}^{S}=\tau_{i j}^{S} r_{L_{i j}}\left(L_{i j}^{S}\right) L_{i j}^{S}-C_{i}(a) L_{i j}^{S}-c_{j} f_{i j}^{S}
\end{gathered}
$$

where $\tau_{i j}$ represents bilateral iceberg transfer cost. $c_{j}$ is country-j-specific multiplier of fixed cost barriers. $C_{j}(a)$ and $C_{i}(a)$ are country-specific variable monitoring cost multiplier. They are functions of unobserved inverse productivity parameter $a$. For tractability, we assume that $C_{j}(a)=a c_{j}-r_{f}, a c_{j}>r_{f} \forall j$.

The interest rate each bank charges for a loan depends on the size of the lending. Following Fillat (2017), we assume a constant-elasticity loan demand function. $L_{i j}\left(r_{L_{i j}}^{C B}\right)=r_{L_{i j}}^{-\varepsilon_{C B}} A_{i}^{C B}$, where $A_{i}^{C B}$ is the total direct cross-border loan market size of the destination country and $\varepsilon_{C B}$ is the demand elasticity of direct cross-border lending. One can make similar assumption for local affiliate lending. The solution to the bank's problem for each type of lending is a multiplicative function of the endogenous variables.

We aggregate each bank's optimal solution to country level by assuming that $1 /$ a follows a truncated Pareto distribution. Integrating individual loan function from the optimization problem across the continuous inverse productivity distribution, and further assuming $\left(\tau_{i j}^{C B}\right)^{\varepsilon_{C B}}=D_{i j}^{\gamma^{C B}} e^{-u_{i j}^{C B}}$, where $D_{i j}$ represents the symmetric distance (gravity factor) between country $i$ and $j$ and $u_{i j}^{C B}$ is a standard disturbance term, we arrive at a log-linear equation estimable using country-level data:

$$
c b_{i j}=\beta_{0}^{C B}+\lambda_{j}^{C B}+\chi_{i}^{C B}+\gamma d_{i j}+w_{i j}^{C B}-u_{i j}^{C B}
$$

where $c b_{i j}$ is the log level of direct cross-border flow. $\lambda_{j}^{C B}$ and $\chi_{i}^{C B}$ denote lender and borrower fixed effects. $d_{i j}$ is the log-transformed symmetric distance. A similar equation can be derived for local affiliate lending. 
It remains to introduce $w_{i j}^{C B}$. In the model, each bank enters direct cross-border lending if it earns non-negative additional profit. Therefore, there exists some cutoff inverse productivity level $a_{i j}^{C B}$ such that only banks below this threshold will engage in direct cross-border lending. $w_{i j}^{C B}$ can be written as a function of this threshold, demand elasticity of direct cross-border lending, and shape and bound parameters of the Pareto distribution. This parameter intuitively controls for the fraction of banks lending direct cross-border. Following Helpman, Melitz and Rubinstein (2008), Cerutti and Zhou (2018) show that $w_{i j}^{C B}$ can be estimated from $\ln \left\{\exp \left[\delta\left(z_{i j}^{C B}+\overline{\eta_{i j}^{C B}}\right)\right]-1\right\} . z_{i j}^{C B}$ and $\overline{\eta_{i j}^{C B}}$ in the expression are derived from a Probit equation. Formally, the Probit equation can be written as

$$
\rho_{i j}^{C B}=\Phi\left(\gamma_{0}^{C B}+\xi_{j}^{C B}+\zeta_{i}^{C B}+\gamma^{C B} d_{i j}-\kappa^{C B} \phi_{i j}^{C B}\right)
$$

where $\xi_{j}^{C B}$ and $\zeta_{i}^{C B}$ are lender and borrower fixed effects. $\phi_{i j}^{C B}$ is the fixed cost shifter. This variable appears in the Probit equation but not in the log-linear equation, thus serving as additional excluded variable (instrument) to facilitate identification. With the estimate of $\rho_{i j}^{C B}$ denoted as $\widetilde{\rho_{i j}^{C B}}$, $z_{i j}^{C B}$ and $\overline{\eta_{i j}^{C B}}$ can be expressed as

$$
z_{i j}^{C B}=\Phi^{-1}\left(\widetilde{\rho_{i j}^{C B}}\right), \overline{\eta_{i j}^{C B}}=\phi\left(z_{i j}^{C B}\right) / \Phi\left(z_{i j}^{C B}\right) \text { (inverse Mills ratio). }
$$

We thus arrive at the two-step estimation procedure described in the main text. The case for local affiliate lending is similar to direct cross-border. To add a time dimension to the estimating equation, one can assume that the country-specific terms are time-varying, and each term can be decomposed into a time-invariant fixed effect, and a time varying component whose effect is to be estimated. For instance, $\lambda_{j t}^{C B}$ in the time-varying log-linear equation can be accordingly written as $\lambda_{j}^{C B}+\psi \cdot X_{j t} . X_{j t}$, to be substituted by regulatory measures in the actual estimation, corresponding to the additional (time-varying) variable monitoring costs each bank faces due to regulations.

Counterfactual: we conduct the counterfactual exercise following Helpman, Melitz and Rubinstein (2008). Using our notation in a static setting, and using the direct cross-border flows as an illustration, the implementation consists of the following steps:

1) Using the true data, generate predicted latent variable $z_{i j}^{C B}$ and inverse Mills ratio $\overline{\eta_{i j}^{C B}}$ as required in the actual second-stage estimation, for pairs observed connected (i.e. with positive net flows). For pairs not observed connected (i.e. with non-positive net flows), extend the definition of $\overline{\eta_{i j}^{C B}}$ such that

$$
\overline{\eta_{i j}^{C B}}= \begin{cases}\frac{-\phi\left(z_{i j}^{C B}\right)}{1-\Phi\left(z_{i j}^{C B}\right)}, & \text { if } T_{i j}^{C B}=0 \\ \frac{\phi\left(z_{i j}^{C B}\right)}{\Phi\left(z_{i j}^{C B}\right)}, & \text { if } T_{i j}^{C B}=1\end{cases}
$$

where $T_{i j}^{C B}$ is an indicator valued one if country $i$ and $j$ is observed to be connected in the data.

2) Suppose we switch lender's regulatory barrier, denoted by $r_{i}$, to $r_{i}^{\prime}$. A new counterfactual estimate of the latent variable $z_{i j}^{C B}$ is obtained from the original first-stage estimates as $z_{i j}^{C B^{\prime}}$. 
Using the same second-stage parameters estimated from the true data, generate predicted counterfactual flows $c b_{i j}^{c}$ for pairs with positive $z_{i j}^{C B^{\prime}}+\overline{\eta_{i j}^{C B}}$ (i.e. pairs that are supposed to be connected counterfactually) using the second stage equation

$$
c b_{i j}^{c}=\beta_{0}+\lambda_{i}+\xi_{j}+\beta_{2} r_{i}^{\prime}+\theta_{2} r_{j}+\gamma_{2} d_{i j}+\ln \left\{\exp \left[\delta\left(z_{i j}^{C B^{\prime}}+\overline{\eta_{i j}^{C B}}\right)-1\right]\right\}+\beta \overline{\eta_{i j}^{C B}}
$$

Note that $\overline{\eta_{i j}^{C B}}$ is a function of the original estimate $z_{i j}^{C B}$ instead of the counterfactual estimate $z_{i j}^{C B^{\prime}}$.

3) Using the original second-stage estimates, generate predicted flows using true data, $c b_{i j}^{p}$. Aggregate both estimates of flows by year and compare. 


\section{Appendix A.2. Additional Tables and Counterfactual Figures}

\begin{tabular}{|c|c|c|c|}
\hline & & Direct Cross-Border & Local Affiliate \\
\hline \multirow{6}{*}{ Overall } & & $0.0337 * * *$ & -0.00280 \\
\hline & Lender & $(0.00554)$ & $(0.00494)$ \\
\hline & & $-0.0149 * * *$ & 0.00292 \\
\hline & Borrower & $(0.00542)$ & $(0.00459)$ \\
\hline & $\mathrm{N}$ & 19998 & 15973 \\
\hline & Pseudo R-sq & 0.154 & 0.225 \\
\hline \multirow{6}{*}{ LTV } & \multirow{2}{*}{ Lender } & $0.0885 * * *$ & -0.0155 \\
\hline & & $(0.0158)$ & $(0.0126)$ \\
\hline & \multirow{2}{*}{ Borrower } & -0.0156 & -0.000541 \\
\hline & & $(0.0154)$ & $(0.0119)$ \\
\hline & $\mathrm{N}$ & 19998 & 15973 \\
\hline & Pseudo R-sq & 0.153 & 0.225 \\
\hline \multirow{6}{*}{ Leverage Ratio } & \multirow{2}{*}{ Lender } & $0.115 * * *$ & $0.0270 *$ \\
\hline & & $(0.0229)$ & $(0.0161)$ \\
\hline & \multirow{2}{*}{ Borrower } & -0.00920 & 0.0149 \\
\hline & & $(0.0202)$ & $(0.0186)$ \\
\hline & $\mathrm{N}$ & 19998 & 15973 \\
\hline & Pseudo R-sq & 0.153 & 0.225 \\
\hline \multirow{6}{*}{ Interbank Exposure } & \multirow{2}{*}{ Lender } & $0.101 * * *$ & $0.0355 * *$ \\
\hline & & $(0.0194)$ & $(0.0167)$ \\
\hline & \multirow{2}{*}{ Borrower } & -0.0321 & -0.00867 \\
\hline & & $(0.0220)$ & $(0.0150)$ \\
\hline & $\mathrm{N}$ & 19998 & 15973 \\
\hline & Pseudo R-sq & 0.153 & 0.225 \\
\hline \multirow{6}{*}{ Foreign Currency Loan } & \multirow{2}{*}{ Lender } & $-0.0561 *$ & -0.0301 \\
\hline & & $(0.0320)$ & $(0.0287)$ \\
\hline & \multirow{2}{*}{ Borrower } & -0.0342 & 0.00285 \\
\hline & & $(0.0224)$ & $(0.0164)$ \\
\hline & $\mathrm{N}$ & 19998 & 15973 \\
\hline & Pseudo R-sq & 0.152 & 0.225 \\
\hline
\end{tabular}

Table A2(a): Macroprudential policy and cross-border banking - first-stage specific estimates

Note: Table A2(a) report the effect of various macroprudential policy measures (MPM) on direct cross-border and local affiliate banking flows. Each pair of home/host regulatory measures is added separately into regression specifications in Section 3, controlling for other regulations. For MPM, overall capital outflow / inflow restrictions, monetary policy and bank non-core activity restrictions are added as additional controls. Only the coefficients of interest are reported. First-stage probit average marginal effects are reported, along with standard errors clustered at country-pair level. 


\begin{tabular}{|c|c|c|c|}
\hline & & Direct Cross-Border & Local Affiliate \\
\hline \multirow{5}{*}{ Overall } & Lender (Outflow) & $\begin{array}{l}0.0944 * * * \\
(0.0353)\end{array}$ & $\begin{array}{l}-0.00990 \\
(0.0323)\end{array}$ \\
\hline & & -0.0197 & $0.0746^{* *}$ \\
\hline & Borrower (Inflow) & $(0.0417)$ & $(0.0324)$ \\
\hline & $\mathrm{N}$ & 19998 & 15973 \\
\hline & Pseudo R-sq & 0.154 & 0.225 \\
\hline \multirow{6}{*}{ Bond } & & 0.0229 & -0.0289 \\
\hline & Lender (Outtlow) & $(0.0214)$ & $(0.0199)$ \\
\hline & & 0.0194 & $0.0464 * *$ \\
\hline & Borrower (Inflow) & $(0.0256)$ & $(0.0235)$ \\
\hline & $\mathrm{N}$ & 19998 & 15973 \\
\hline & Pseudo R-sq & 0.153 & 0.225 \\
\hline \multirow{6}{*}{ Commercial Credit } & & $-0.0754 * * *$ & $-0.0617 * * *$ \\
\hline & Lender (Outtlow) & $(0.0275)$ & $(0.0218)$ \\
\hline & & -0.0257 & -0.00137 \\
\hline & Borrower (Inflow) & $(0.0177)$ & $(0.0143)$ \\
\hline & $\mathrm{N}$ & 19926 & 15907 \\
\hline & Pseudo R-sq & 0.154 & 0.225 \\
\hline \multirow{6}{*}{ Foreign Credit } & I & $-0.0363 * *$ & $-0.0306^{* *}$ \\
\hline & Lender (Outflow) & $(0.0158)$ & $(0.0131)$ \\
\hline & Domrouran (Inflour) & 0.00197 & $0.0395 * * *$ \\
\hline & Borrower (IntIow) & $(0.0164)$ & $(0.0129)$ \\
\hline & $\mathrm{N}$ & 19926 & 15907 \\
\hline & Pseudo R-sq & 0.154 & 0.225 \\
\hline
\end{tabular}

Table A2(b): Capital control measures and cross-border banking - first-stage specific estimates

Note: Table A2(b) report the effect of various capital control measures (CCM) on direct crossborder and local affiliate banking flows. Each pair of home/host regulatory measures is added separately into regression specifications in Section 3, controlling for other regulations. For CCM, overall macroprudential index, monetary policy and bank non-core activity restrictions are added as additional controls. Only the coefficients of interest are reported. First-stage probit average marginal effects are reported, along with standard errors clustered at country-pair level. 


\begin{tabular}{|c|c|c|c|c|c|c|c|c|c|c|}
\hline & \multicolumn{2}{|c|}{ Baseline } & \multicolumn{4}{|c|}{ Weighted Inflow to Neighbors } & \multicolumn{4}{|c|}{ Change in Credit to GDP } \\
\hline & Direct Cross-Border & Local Affiliate & Direct C & ss-Border & Local & fffiliate & Direct $C$ & oss-Border & Local & Affiliate \\
\hline Overall & $\begin{array}{l}0.143 \\
(0.279)\end{array}$ & $\begin{array}{l}1.280 \\
(0.924)\end{array}$ & $\begin{array}{l}0.144 \\
(0.279)\end{array}$ & $\begin{array}{l}0.149 \\
(0.279)\end{array}$ & $\begin{array}{l}1.077 \\
(0.902)\end{array}$ & $\begin{array}{l}1.070 \\
(0.902)\end{array}$ & $\begin{array}{l}0.521 \\
(0.340)\end{array}$ & $\begin{array}{l}0.605^{*} \\
(0.345)\end{array}$ & $\begin{array}{l}0.487 \\
(0.874)\end{array}$ & $\begin{array}{l}0.497 \\
(0.912)\end{array}$ \\
\hline Additional Variable & & & $\begin{array}{l}-0.000440 \\
(0.000778)\end{array}$ & $\begin{array}{l}0.000855 \\
(0.00289)\end{array}$ & $\begin{array}{l}0.0866^{* *} \\
(0.0426)\end{array}$ & $\begin{array}{l}0.103^{*} \\
(0.0539)\end{array}$ & $-0.0136^{* *}$ & -0.00781 & $0.0339 * * *$ & $0.0344^{* *}$ \\
\hline Interaction & & & & $\begin{array}{l}-0.00571 \\
(0.0121)\end{array}$ & & $\begin{array}{l}-0.0837 \\
(0.193)\end{array}$ & & $\begin{array}{l}-0.0183 * * \\
(0.00859)\end{array}$ & & $\begin{array}{l}-0.00177 \\
(0.0262)\end{array}$ \\
\hline $\mathrm{N}$ & 6754 & 2379 & 6754 & 6754 & 2379 & 2379 & 6754 & 6754 & 2379 & $\begin{array}{l}(0.0202) \\
2379\end{array}$ \\
\hline Bond & $\begin{array}{l}-0.201 \\
(0.189)\end{array}$ & $\begin{array}{l}0.690 \\
(0.677)\end{array}$ & $\begin{array}{l}-0.203 \\
(0.189)\end{array}$ & $\begin{array}{l}-0.192 \\
(0.189)\end{array}$ & $\begin{array}{l}0.679 \\
(0.674)\end{array}$ & $\begin{array}{l}0.658 \\
(0.674)\end{array}$ & $\begin{array}{l}-0.271 \\
(0.191)\end{array}$ & $\begin{array}{l}-0.0661 \\
(0.188)\end{array}$ & $\begin{array}{l}0.572 \\
(0.673)\end{array}$ & $\begin{array}{l}0.572 \\
(0.696)\end{array}$ \\
\hline Additional Variable & & & $\begin{array}{l}-0.000281 \\
(0.000771)\end{array}$ & $\begin{array}{l}-0.000247 \\
(0.000771)\end{array}$ & $\begin{array}{l}0.0928^{* *} \\
(0.0449)\end{array}$ & $\begin{array}{l}0.0894 * * \\
(0.0448)\end{array}$ & $\begin{array}{l}-0.0107 * \\
(0.00586)\end{array}$ & $\begin{array}{l}-0.00710 \\
(0.00632)\end{array}$ & $\begin{array}{l}0.0344 * * * \\
(0.0118)\end{array}$ & $\begin{array}{l}0.0344 * * * \\
(0.0127)\end{array}$ \\
\hline Interaction & & & & $\begin{array}{l}-0.00833 \\
(0.0107)\end{array}$ & & $\begin{array}{l}0.0453 \\
(0.121)\end{array}$ & & $\begin{array}{l}-0.0102 \\
(0.00645)\end{array}$ & & $\begin{array}{l}-0.0000105 \\
(0.0178)\end{array}$ \\
\hline $\mathrm{N}$ & 6754 & 2379 & 6754 & 6754 & 2379 & 2379 & 6754 & 6754 & 2379 & 2379 \\
\hline Commercial Credit & $\begin{array}{l}-0.0391 \\
(0.128)\end{array}$ & $\begin{array}{l}0.381 \\
(0.318)\end{array}$ & $\begin{array}{l}-0.0370 \\
(0.128)\end{array}$ & $\begin{array}{l}-0.00375 \\
(0.129)\end{array}$ & $\begin{array}{l}0.347 \\
(0.315)\end{array}$ & $\begin{array}{l}0.344 \\
(0.316)\end{array}$ & $\begin{array}{l}0.0755 \\
(0.147)\end{array}$ & $\begin{array}{l}0.719^{* *} \\
(0.320)\end{array}$ & $\begin{array}{l}0.379 \\
(0.320)\end{array}$ & $\begin{array}{l}0.457 \\
(0.333)\end{array}$ \\
\hline Additional Variable & & & $\begin{array}{l}-0.000404 \\
(0.000757)\end{array}$ & $\begin{array}{l}-0.000370 \\
(0.000758)\end{array}$ & $\begin{array}{l}0.0979 * * \\
(0.0445)\end{array}$ & $\begin{array}{l}0.0979 * * \\
(0.0445)\end{array}$ & $\begin{array}{l}-0.0126^{*} \\
(0.00674)\end{array}$ & $\begin{array}{l}-0.00925 \\
(0.00677)\end{array}$ & $\begin{array}{l}0.0360^{* * * *} \\
(0.0116)\end{array}$ & $\begin{array}{l}0.0378^{* * * *} \\
(0.0122)\end{array}$ \\
\hline Interaction & & & & $\begin{array}{l}-0.0395 * * \\
(0.0183)\end{array}$ & & $\begin{array}{l}0.0786 \\
(0.534)\end{array}$ & & $\begin{array}{l}-0.0213 * * * \\
(0.00651)\end{array}$ & & $\begin{array}{l}-0.0187 \\
(0.0190)\end{array}$ \\
\hline $\mathrm{N}$ & 6734 & 2379 & 6734 & 6734 & 2379 & 2379 & 6734 & 6734 & 2379 & 2379 \\
\hline Foreign Credit & $\begin{array}{l}0.0843 \\
(0.106)\end{array}$ & $\begin{array}{l}0.839^{* *} \\
(0.424)\end{array}$ & $\begin{array}{l}0.0837 \\
(0.106)\end{array}$ & $\begin{array}{l}0.123 \\
(0.108)\end{array}$ & $\begin{array}{l}0.744 * \\
(0.408)\end{array}$ & $\begin{array}{l}0.750^{*} \\
(0.423)\end{array}$ & $\begin{array}{l}0.186 \\
(0.120)\end{array}$ & $\begin{array}{l}0.303 * * \\
(0.130)\end{array}$ & $\begin{array}{l}0.641 \\
(0.405)\end{array}$ & $\begin{array}{l}0.694 \\
(0.462)\end{array}$ \\
\hline Additional Variable & & & $\begin{array}{l}-0.000561 \\
(0.000768)\end{array}$ & $\begin{array}{l}-0.000521 \\
(0.000769)\end{array}$ & $\begin{array}{l}0.0793 * \\
(0.0411)\end{array}$ & $\begin{array}{l}0.0794 * \\
(0.0411)\end{array}$ & $\begin{array}{l}-0.0158^{* *} \\
(0.00747)\end{array}$ & $\begin{array}{l}-0.0131^{*} \\
(0.00761)\end{array}$ & $\begin{array}{l}0.0332^{* * *} \\
(0.0116)\end{array}$ & $\begin{array}{l}0.0341 \text { *** } \\
(0.0122)\end{array}$ \\
\hline Interaction & & & & $\begin{array}{l}-0.0128 \\
(0.0109)\end{array}$ & & $\begin{array}{l}-0.00628 \\
(0.152)\end{array}$ & & $\begin{array}{l}-0.0151 * * * \\
(0.00570)\end{array}$ & & $\begin{array}{l}-0.00592 \\
(0.0198)\end{array}$ \\
\hline $\mathrm{N}$ & 6734 & 2379 & 6734 & 6734 & 2379 & 2379 & 6734 & 6734 & 2379 & 2379 \\
\hline
\end{tabular}

Table A2(c): Borrowers' capital control measures and cross-border banking: Interaction with credit cycles

Note: Table A2(c) reports second-stage regression coefficients of borrower's capital inflow control measures and their interaction with credit cycle proxies ("additional variable"). For each borrower, "weighted inflow to neighbors" is the distance-GDP-weighted average flow to the borrower's regional peers. "Change in Credit to GDP" is the year-over-year change in credit to GDP ratio. Only the coefficients of interest are reported. Second-stage ML estimates are reported, along with standard errors clustered at country-pair level. 


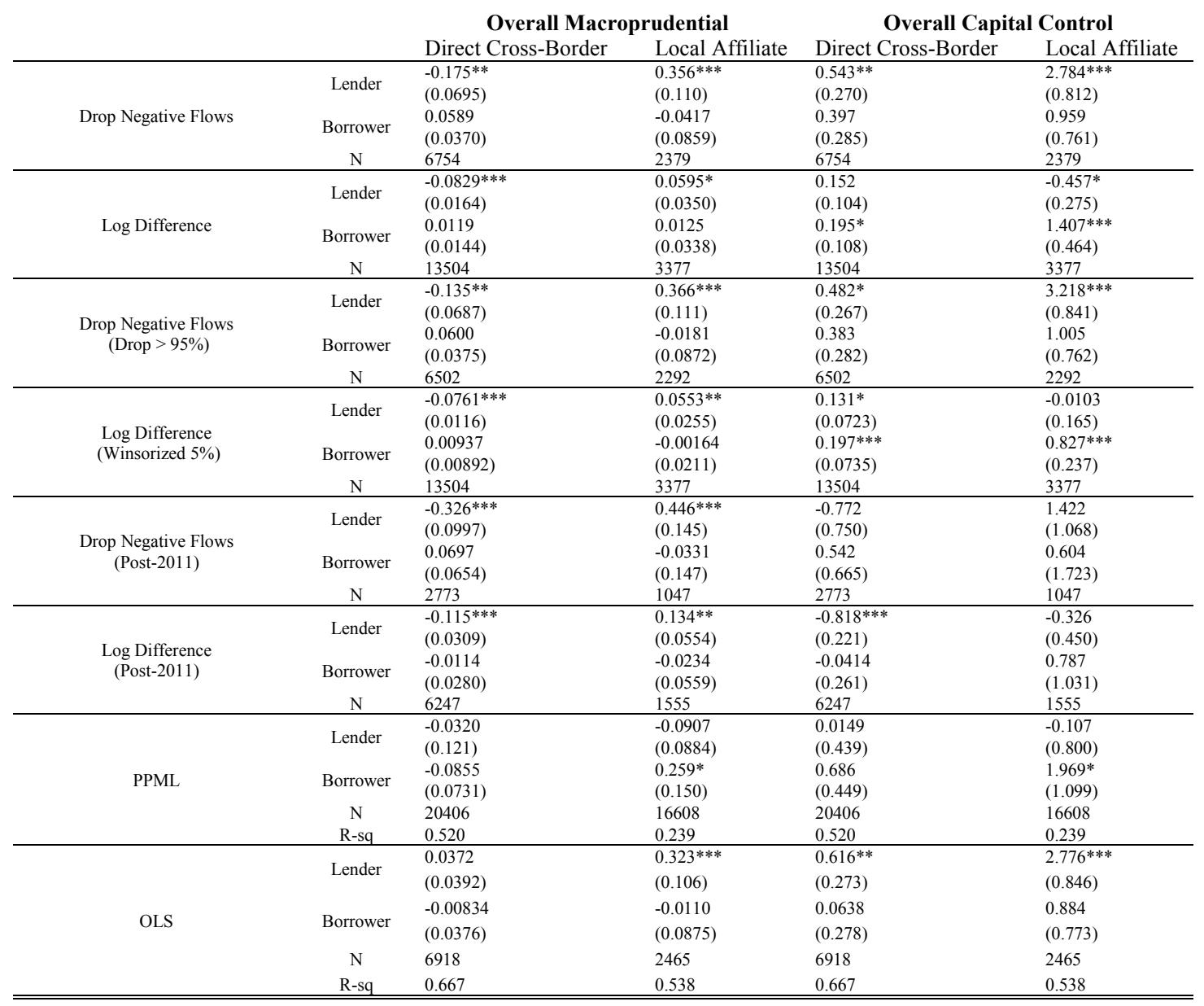

Table A2(d): Effect of overall macroprudential policies and capital controls on cross-border banking - Alternative definition of dependent variables / Alternative methodology

Note: Table A2(d) reports estimation results on the effect of overall macroprudential policies and capital controls on cross-border banking, using different definition of first-stage and secondstage dependent variables. "Drop negative flows" refers to the definition, under which all negative changes to direct cross-border and local affiliate exposures are dropped, and the first-stage binary indicator of banking connection is redefined to be one when direct cross-border / local affiliate exposures are positive, and zero otherwise. Under this definition, the second-stage dependent variable is kept to be the log of positive changes in exposure. "Log difference" refers to the definition under which the first-stage binary indicator of banking connection is redefined to be one when direct cross-border / local affiliate exposures are positive, and zero otherwise, and the second-stage dependent variable is redefined to be the log difference (growth rate) of direct cross-border / local affiliate exposures. Additional data transformation (winsorization, right censoring, restriction to post-2011 sample) is performed and the transformed data is used to estimate additional cases. PPML refers to the Poisson Pseudo-maximum Likelihood estimator of Santos Silva and Tenreyro (2006). OLS is the ordinary least squares estimator, which is used instead of maximum likelihood. In all cases, standard errors are clustered at country-pair (lender-borrower) level. 

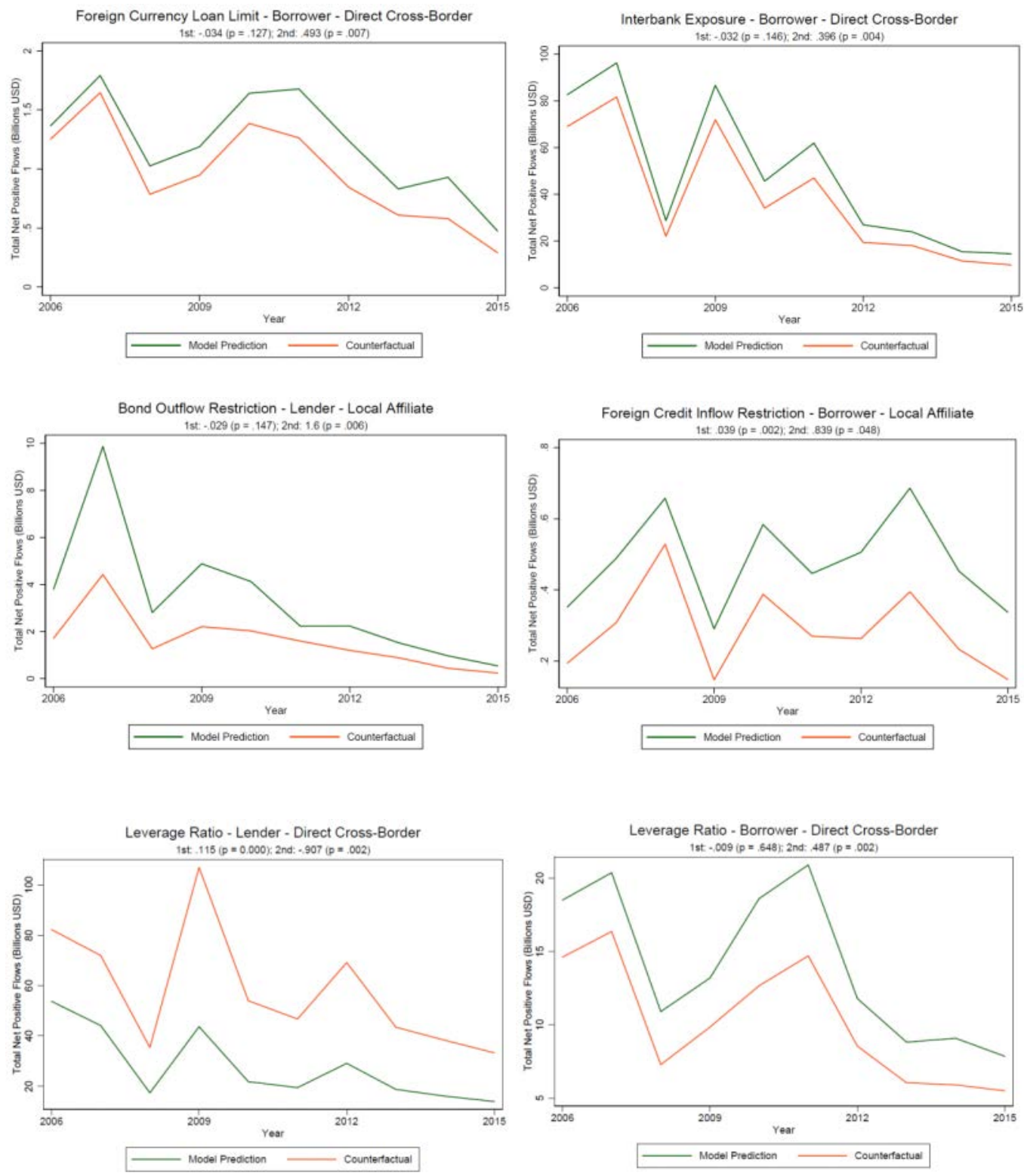

Figure A2(a): Additional counterfactual figures - Specific macroprudential and capital control instruments

Note: Figure A2(a) reports additional results of the counterfactual exercise detailed in Section 3 and Appendix A1. The variables of interest are specific macroprudential and capital control measures. "Model prediction" refers to the numbers predicted by the second-stage equation, using parameters estimated from true data. "Counterfactual" refers to the scenario where existing measures are switched off. Counterfactual numbers are generated using the procedure outlined in Appendix A1. For each policy instrument, model prediction and counterfactual calculation are generated based on a sample of lenders/borrowers that have ever adopted this instrument. For each year, the magnitude of net positive increase in direct cross-border and local affiliate exposure is predicted for each country pair in the sample, and summed to global level. 